\title{
Low-Intensity Repetitive Transcranial Magnetic Stimulation Improves Abnormal Visual Cortical Circuit Topography and Upregulates BDNF in Mice
}

\author{
Kalina Makowiecki, ${ }^{1}$ Alan R. Harvey, ${ }^{1,2}$ Rachel M. Sherrard, ${ }^{3}$ and Jennifer Rodger ${ }^{1}$ \\ ${ }^{1}$ Experimental and Regenerative Neuroscience, School of Animal Biology, and ${ }^{2}$ School of Anatomy, Physiology and Human Biology, The University of \\ Western Australia, Crawley, Western Australia 6009, and ${ }^{3}$ Sorbonne Universités, Pierre and Marie Curie University of Paris 06 and Centre National de la \\ Recherche Scientifique, Institut de Biologie Paris Seine, UMR8256 Biological Adaptation and Ageing, F-75005 Paris, France
}

Repetitive transcranial magnetic stimulation (rTMS) is increasingly used as a treatment for neurological and psychiatric disorders. Although the induced field is focused on a target region during rTMS, adjacent areas also receive stimulation at a lower intensity and the contribution of this perifocal stimulation to network-wide effects is poorly defined. Here, we examined low-intensity rTMS (LI-rTMS)induced changes on a model neural network using the visual systems of normal (C57Bl/6J wild-type, $n=22)$ and ephrin-A2A $5^{-1-}(n=$ 22) mice, the latter possessing visuotopic anomalies. Mice were treated with LI-rTMS or sham (handling control) daily for $14 \mathrm{~d}$, then fluorojade and fluororuby were injected into visual cortex. The distribution of dorsal LGN (dLGN) neurons and corticotectal terminal zones (TZs) was mapped and disorder defined by comparing their actual location with that predicted by injection sites. In the afferent geniculocortical projection, LI-rTMS decreased the abnormally high dispersion of retrogradely labeled neurons in the dLGN of ephrin$\mathrm{A} 2 \mathrm{~A} 5^{-1-}$ mice, indicating geniculocortical map refinement. In the corticotectal efferents, LI-rTMS improved topography of the most abnormal TZs in ephrin-A2A $5^{-1-}$ mice without altering topographically normal TZs. To investigate a possible molecular mechanism for LI-rTMS-induced structural plasticity, we measured brain derived neurotrophic factor (BDNF) in the visual cortex and superior colliculus after single and multiple stimulations. BDNF was upregulated after a single stimulation for all groups, but only sustained in the superior colliculus of ephrin-A2A $5^{-1-}$ mice. Our results show that LI-rTMS upregulates BDNF, promoting a plastic environment conducive to beneficial reorganization of abnormal cortical circuits, information that has important implications for clinical rTMS.

Key words: corticotectal projection; critical period; ephrin-A2A $5^{-/-}$mice; geniculocortical; LI-rTMS; plasticity

\section{Introduction}

Activity-dependent mechanisms are necessary for maintaining neural circuits throughout life (Butz et al., 2009) and promoting plasticity during learning and memory (Martin et al., 2000). However, the ability to reorganize the structure and function of neural circuits is largely restricted to a critical period of development. Therefore, adults with neurological and psychiatric disorders, many of which are associated with neural circuit and

\footnotetext{
Received Feb. 18, 2014; revised June 11, 2014; accepted July 6, 2014.

Author contributions: K.M., A.R.H., R.M.S., and J.R. designed research; K.M. and J.R. performed research; K.M., A.R.H., and J.R. analyzed data; K.M., A.R.H., R.M.S., and J.R. wrote the paper.

This work was supported by the National Health and Medical Research Council (NHMRC) Australia (project grant), the Australian Research Council (linkage grant), and the Neurotrauma Research Program (project grant to J.R., funded through the Road Trauma Trust Account, but does not reflect views or recommendations of the Road Safety Council). K.M. receives doctoral scholarship support from The University of Western Australia and an Australian Postgraduate Award. J.R. is an NHMRC Senior Research Fellow. We thank Andrew Garrett, Mark Hinder, and Gary Thickbroom for useful comments on the manuscript; Don Robertson for advice and assistance with coil sound measurements; Joao Paulo Coimbra for histology advice; and Marissa Penrose-Menz for technical assistance.

The authors declare no competing financial interests.

Correspondence should be addressed to Jennifer Rodger, Experimental and Regenerative Neuroscience M317, School of Animal Biology, University of Western Australia, 35 Stirling Highway, Crawley, Western Australia 6009. E-mail: jennifer.rodger@uwa.edu.au.

DOI:10.1523/JNEUROSCI.0723-14.2014

Copyright $\odot 2014$ the authors $\quad 0270-6474 / 14 / 3410780-13 \$ 15.00 / 0$
}

plasticity abnormalities (Thickbroom and Mastaglia, 2009; Arnsten and Rubia, 2012), have limited capacity for repair.

Noninvasive brain stimulation techniques such as repetitive transcranial magnetic stimulation (rTMS) are thought to facilitate neural plasticity and demonstrate clinical promise in treating many neurological and psychiatric disorders (Wassermann and Zimmermann, 2012). rTMS uses trains of magnetic pulses to induce electric currents in the brain that modulate cortical activity (Pascual-Leone, 2006) and can produce persistent excitability and behavioral modifications (Maeda et al., 2000; Valero-Cabré et al., 2005). Although these changes are generally attributed to induced neuronal spiking within the stimulated region (Zangen et al., 2005), associated activation of the wider network also contributes to rTMS-induced functional plasticity (Lee et al., 2003; Rounis et al., 2006). This is consistent with rTMS modulating metabolism (Valero-Cabré et al., 2005; Valero-Cabré et al., 2007) and gene expression (Aydin-Abidin et al., 2008) in regions downstream of the target area.

However, the induced field is not restricted to the target region of rTMS: perifocal areas also receive stimulation, albeit at lower intensities, below the neuron firing threshold (Wagner et al., 2009). Although the functional importance of this perifocal subthreshold stimulation is unclear, it may contribute to 
A

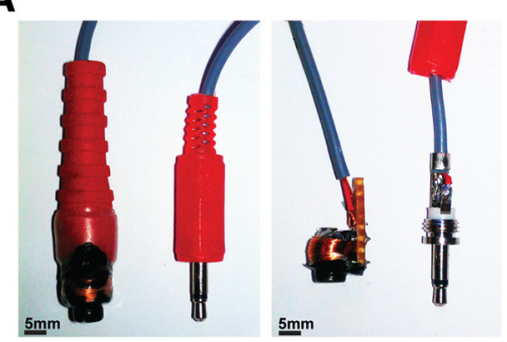

B

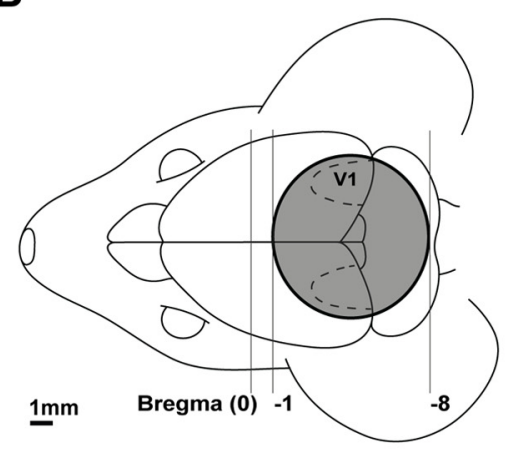

C

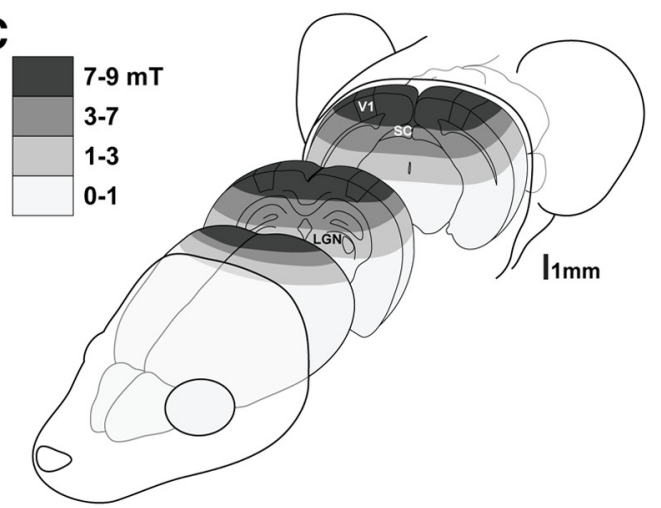

Figure 1. Method of LI-rTMS delivery in mice. $A$, Custom-built stimulation coil and $3.5 \mathrm{~mm}$ jack used to connect to the pulse generator, modified for its attachment. Coil and jack are shown with (left) and without (right) protective plastic coating. $\boldsymbol{B}$, Diagram of the stimulation coil in relation to the mouse's head, showing stereotaxic coordinates. The coil was held close to the mouse's head along the midline above the visual cortices, ensuring bilateral stimulation. C, Schematic diagram of estimated (Hall device) magnetic field intensity (in milli-teslas) in the mouse head showing approximate range of field intensities received by brain regions at different depths. The magnetic field is focal to posterior brain regions and thus more focal than the broad stimulation resulting from the use of human coils in mice (Salvador and Miranda, 2009). However, stimulation remains less focal than that induced by butterfly-shaped coils when used in human rTMS studies (Deng et al., 2013).

network-wide effects. Support for this hypothesis comes from human studies which show that low-intensity rTMS (LI-rTMS) modifies cortical excitability (Cook et al., 2004; Capone et al., 2009), alters pain perception (Robertson et al., 2010), and alleviates depression symptoms (Martiny et al., 2010). Moreover, animal and in vitro studies demonstrate that low-intensity magnetic stimulation alters calcium signaling (Pessina et al., 2001), gene expression (Mattsson and Simkó, 2012), neurotransmitter synthesis (Sieron et al., 2004), and the structure and function of a single neural pathway (Rodger et al., 2012). Together, these studies suggest that LI-rTMS, like suprathreshold stimulation (Valero-Cabré et al., 2005; Valero-Cabré et al., 2008; Reithler et al., 2011), may have network-wide effects.

In the present study, we evaluate to what extent LI-rTMS induces structural reorganization in afferent and efferent pathways within a network. We use a well-defined model, the mouse visual system, which has topographic projections between multiple centers. We examined LI-rTMS effects on the afferent geniculocortical [dorsal LGN (dLGN) to primary visual cortex (V1)] and the efferent corticotectal (V1 to superior colliculus) projections in both normal (wild-type) and abnormal (ephrin$\mathrm{A} 2 \mathrm{~A} 5^{-1-}$ ) adult mice, which have ectopic terminals in addition to normally located projections (Haustead et al., 2008; Wilks et al., 2010). To examine a possible mechanism underlying structural reorganization, we measured BDNF expression in the visual cortex and superior colliculus of wild-type and ephrin-A2 $\mathrm{A} 5^{-1-}$ mice after a single stimulation or after multiple LI-rTMS sessions.

\section{Materials and Methods}

Subjects and housing. Ephrin-A2A $5^{-1-}$ mice were originally a generous gift from David Feldheim and carry a homozygous-null mutation of the ephrin-A2 and A5 genes (Feldheim et al., 2000). Ephrin-A2A5 ${ }^{-1-}$ mice were bred from heterozygous parents and were backcrossed for $>10$ generations on a $\mathrm{C} 57 \mathrm{Bl} / 6 \mathrm{~J}$ background. Mice were genotyped at weaning, as described previously (Feldheim et al., 2000). Wild-type mice of the same genetic background were purchased from the Animal Research Centre of Murdoch University (Perth, Western Australia). Mice were bred in the Biomedical Research Facility of The University of Western Australia and housed in single-sex cages on a $12 \mathrm{~h}$ light/dark cycle with food and water provided ad libitum. Anatomical and BDNF data were obtained from separate cohorts because of tissue-processing differences and to avoid the potential confounder of minor injury from the tracer injection altering BDNF expression (Hicks et al., 1997). Mice in both cohorts were mature young adults (2-7 months old; Grillo et al., 2013) and we confirmed there was no significant age effect on any measure (all $p>0.05)$. All procedures in this study were in accordance with National Institutes of Health guidelines and were approved by The University of Western Australia Animal Ethics Committee.

LI-rTMS administration. For anatomical experiments, mice received either LI-rTMS or sham (no stimulation, handling control) for $10 \mathrm{~min}$ daily for $14 \mathrm{~d}$. Magnetic pulses were generated using an electromagnetic pulse generator (Global Energy Medicine) connected to mains power by a standard $9 \mathrm{~V} \mathrm{AC/DC}$ adaptor. The pulse generator was wired to a 3.5 $\mathrm{mm}$ jack (Jaycar) for attachment of a custom-built circle coil suitable for use on mice (Fig. $1 A, B$ ). The coil (copper wire, $0.25 \mathrm{~mm}$ diameter, $16 \Omega$, 300 windings; Jaycar) had an $8 \mathrm{~mm}$ outer diameter and $6 \mathrm{~mm}$ inner diameter and was filled with a steel bolt to increase field penetration (Epstein and Davey, 2002). The coil was designed to achieve a similar coil-to-brain size ratio as used in humans, enabling focal stimulation of the head (Weissman et al., 1992). However, the magnetic field produced by our custom-built coils obviously differs from standardized devices currently used in human TMS/rTMS research (Lang et al., 2006; Ziemann et al., 2008; Lefaucheur, 2009).

Using a Hall device to measure magnetic field strength (Rodger et al., 2012), the coil generated a $12 \mathrm{mT}$ magnetic field at its base, a programmed voltage input pulse width of $220 \mu$ s, and measured field rise time of $230 \mu \mathrm{s}$, which did not vary within the $10 \mathrm{~min}$ LI-rTMS session or between sessions. The field at the visual cortex was estimated to be $\sim 8$ $\mathrm{mT}$ (Fig. 1C). This intensity is within the range known to affect cellular biochemistry (Morgado-Valle et al., 1998; Arias-Carrión et al., 2004), yet is below motor threshold, obviating the need for anesthetic or restraint, with their associated changes to neuronal excitability and circulating stress hormones (Gersner et al., 2011).

We delivered a high-frequency complex pattern of stimulation comprising $59.9 \mathrm{~ms}$ trains of 20 pulses, with trains repeated at $6.67 \mathrm{~Hz}$ for 1 $\mathrm{min}, 10.01 \mathrm{~Hz}$ for $8 \mathrm{~min}$, and $6.25 \mathrm{~Hz}$ for the final minute (Rodger et al., 2012). This pattern was developed from electrobiomimetic principles to replicate endogenous patterns of electrical fields around activated nerves during exercise (Martiny et al., 2010) and is based on the patent PCT/ AU2007/000454 of Global Energy Medicine. This pattern and intensity is consistent with the concept of a subthreshold "priming" stimulation at one frequency modulating cortical responsiveness to subsequent stimulation, as previously demonstrated using different combinations of stimuli (Iyer et al., 2003; Hamada et al., 2008).

To ensure that mice remained relatively still without restraint during LI-rTMS, they were habituated to handling and the coil for $3 \mathrm{~d}$ before the study, as described previously (Rodger et al., 2012). During stimulation, the coil was held between the ears, allowing reproducible targeting of 
visual cortices bilaterally (Fig. $1 B$ ). It was held above, but not in contact with, the head to ensure that any potential vibration of the coil could not confound the sham-stimulation procedure, in which the stimulator was switched off. After $10 \mathrm{~min}$ of stimulation, coil temperature was $26.5^{\circ} \mathrm{C}$ at the coil surface and $25.5^{\circ} \mathrm{C} 1 \mathrm{~mm}$ from the thermometer. Because this is within the range of room temperature $\left(22-26^{\circ} \mathrm{C}\right)$, confounding effects of heat are unlikely. We also verified that the active coil did not emit audible or ultrasonic sound. The sound output emitted by the coil was measured in a sound proofed room using a 1/2-inch Bruel and Kjaer Type 4134 condensor microphone and a Hewlett Packard 3561A Dynamic Signal Analyzer. The microphone was positioned approximately the same distance from the coil as the animal's ear. Absolute sound intensity was calibrated using a Bruel and Kjaer Type 4231 sound calibrator. The maximum acoustic energy emitted was at $1.3 \mathrm{kHz}$ and $37 \mathrm{~dB}$ SPL. At $8 \mathrm{kHz}$, the sound intensity had fallen to $10 \mathrm{~dB}$ SPL, which was only $7 \mathrm{~dB}$ above background. Above $10 \mathrm{kHz}$, there was no detectable acoustic energy emitted above background, which averaged $9 \mathrm{~dB}$ SPL from 10 to $20 \mathrm{kHz}$ (measured with the LI-rTMS device turned off). This sound intensity $(<7 \mathrm{~dB}$ in the frequency range detectable by mice) is below the auditory threshold $(30 \mathrm{~dB})$ for wild-type (Fernandez et al., 2010) and ephrinA2A5 ${ }^{-1-}$ mice (Yates et al., 2014). Therefore, consistent with the low stimulation intensity and lack of auditory or heat/tactile confounders, mice did not display any gross motor, visuomotor, or behavioral response to either the stimulation or sham procedure.

Anatomical tracing of cortical projections. On the $15^{\text {th }}$ day after beginning sham or LI-rTMS, mice were anesthetized with xylazine $(10 \mathrm{mg} / \mathrm{kg})$ and ketamine $(70 \mathrm{mg} / \mathrm{kg})$. Mice were placed in a stereotaxic frame and a small part of the skull and dura were removed to expose the left primary visual cortex (V1), which was identified based on stereotaxic coordinates (Mouse Brain Atlas, Franklin and Paxinos, 2008) and confirmed visually using a landmark surface branch of the middle cerebral artery (Dorr et al., 2007). Injections into V1 were between $0.05 \mathrm{~mm}$ caudal and $1.5 \mathrm{~mm}$ rostral to lambda and 1.5 to $3 \mathrm{~mm}$ from the midline. Each mouse received two injections of fluorescent tracers, biotinylated dextran amine (BDA; 10,000 MW; Life Technologies): Alexa Fluor 488 (fluorojade) for the lateral injection and Alexa Fluor 555 (fluororuby) for the medial injection. Tracers were pressure injected using a nanojet injector fitted with a micropipette attached to a micromanipulator. The micropipette was lowered to $400 \mu \mathrm{m}$ from the cortex surface to target layer 5 neurons, which project to the superior colliculus, and layer 4 geniculocortical axon terminals. Six $50 \mathrm{~nL}$ pulses of tracer were injected at each site.

Four days after cortical injections, mice were killed by intraperitoneal injection of $0.1 \mathrm{ml}$ of sodium pentobarbitone (Lethabarb; Virbac) and transcardially perfused with $80 \mathrm{ml}$ of $4 \%$ paraformaldehyde in $0.2 \mathrm{M}$ phosphate buffer. The brain was dissected and postfixed for $24 \mathrm{~h}$ at $4{ }^{\circ} \mathrm{C}$ before cryoprotection in graded concentrations of sucrose $(15 \%, 30 \%)$ in PBS, which were changed after $24 \mathrm{~h}$.

Brains were cryosectioned coronally $(40 \mu \mathrm{m})$ and three parallel series of sections were collected onto gelatin-subbed slides. One of the series was used to visualize fluorescent tracers. Sections were dried on slides for 5 min before immersion in PBS for 2 min to remove optimal cutting temperature (OCT) embedding medium, dried for a further $5 \mathrm{~min}$, and coverslipped with Dakomount mounting medium (Dako). Sections were examined using a Nikon fluorescent microscope and photographed using a cooled digital camera (QuantiFIRE; Optronics). The adjacent second series was stored at $-80^{\circ} \mathrm{C}$ and selected slides were processed for fluorescent microscopy to confirm terminal zones (TZs) when cases in series 1 were ambiguous. Images of fluorescent sections were analyzed using Adobe Photoshop (CS6 version 13.1).

The third series was Nissl stained to measure dLGN volume and to confirm the location of injection sites within V1. Slides were air-dried, immersed in distilled water for $2 \mathrm{~min}$ (to remove OCT), heated to 50$60^{\circ} \mathrm{C}$ in ethanol with $5 \%$ glacial acetic acid solution, and then cooled to room temperature $(2 \mathrm{~h})$. Sections were rehydrated in distilled water $(2$ $\min )$, stained in prewarmed $\left(55^{\circ} \mathrm{C}\right)$ cresyl violet acetate $(0.5 \%$; Proscitech) for $8 \mathrm{~min}$, and then differentiated in ethanol with $5 \%$ glacial acetic acid for up to $13 \mathrm{~min}$ before dehydration in ethanol $(3 \times 3 \mathrm{~min})$ and xylene $(2 \times 2 \mathrm{~min})$, and mounted with Entellan (Merck). Slides with Nissl-stained sections were scanned for image analysis using an Aperio
ScanScope and analyzed using Aperio ImageScope software (version 10.2.2.2352).

Analyses of anatomical tracing. All analyses of anatomical tracing were performed blinded to stimulation condition. It was not possible to blind to genotype as well, because the presence or absence of additional TZs made the genotype apparent. We confirmed that injections were at an appropriate depth in V1 by examining fluorescent sections crosschecked against adjacent Nissl-stained sections and regions defined in the mouse brain atlas (Franklin and Paxinos, 2008). We tested for group differences in injection size by thresholding images to remove background (Haustead et al., 2008) and measuring the labeled area for each injection site in sections from a single series. To obtain injection volume (in cubic micrometers), area measures were summed and then multiplied by section thickness $(40 \mu \mathrm{m})$ and the number of series. We applied the same method to obtain volumes of corticotectal TZs and dLGN measures.

We determined topography of the corticotectal projection by reconstructing TZlocations in the superior colliculus using every third section. Multiple TZs were scored if TZs were separated by at least one section in the examined series (i.e., $>120 \mu \mathrm{m}$ in the rostrocaudal axis) or visually distinct from an adjacent TZ (mediolateral axis; Wilks et al., 2010). There is an established relationship between cortical injection site on the mediolateral axis and TZ location in superior collicular rostrocaudal axis, with lateral injections resulting in rostral labeling and medial injections resulting in caudal labeling (Triplett et al., 2009; Wilks et al., 2010). Accordingly, we examined topography by analyzing injection site location mediolaterally as a function of TZ location rostrocaudally. Injection site location mediolaterally was defined as the distance from approximate injection center-point to the midline as a percentage of the total cortical hemisphere width (measured using Photoshop). TZlocation was defined as the distance from the midpoint (rostrocaudally) of the TZ to the caudal extreme of the superior colliculus as a percentage of the total superior colliculus length in the rostrocaudal axis measured by multiplying number of sections by inter-section distance.

In a separate analysis, we distinguished between topographically normal and abnormal TZs within each mouse, using relative position in the azimuth axis (degrees) of a Cartesian plane for the medial (red) to lateral (green) injection sites and corresponding red-green TZs pairs. We restricted this analysis to mice in which both injections successfully labeled TZs. The difference from the predicted relative location was determined for each $\mathrm{TZ}$ pair using residuals from linear regression constrained to a perfect-fit (intercept $=0$, slope $=1$ ), with injection azimuth as the predictor and TZ azimuth as the outcome variable. Within each mouse, $\mathrm{TZ}$ pairs were ranked to determine the least disordered (closest to predicted location) and the most disordered (farthest from predicted location). We obtained TZ volumes for each distinct TZ (in cubic micrometers) as described for injection volume. Volumes were summed for the same TZ pairs used in the assessment of topographical disorder. Because all wild-type mice had only a single TZ per injection, data were included in analyses for both least and most disordered TZs. Two ephrinA2A $5^{-1-}$ LI-rTMS mice had only a single TZ per injection and were included in both the least and most disordered $\mathrm{TZ}$ analyses because comparison between $\mathrm{TZ}$ pairs was not possible.

To assess LI-rTMS effects on the geniculocortical projection, we quantified the spatial distribution of retrogradely labeled neurons in the dLGN measured as cell dispersion and labeled cluster size. Cell dispersion was measured as the area defined by straight lines joining the outermost labeled neurons (convex-hull) in each section, converted to volume (in cubic micrometers). To control for dLGN size differences between mice, convex-hull volume was normalized to total dLGN volume obtained by measuring dLGN area in each Nissl-stained section (one series) and multiplying by inter-section distance. We also measured the mean area of the main labeled cluster from three representative sections for each animal. We averaged the area from three sections within the middle range of labeled dLGN sections instead of total cluster volume because labeling was too sparsely distributed at the rostral and caudal extremes, so cluster boundaries could not be identified accurately. The number of retrogradely labeled neurons was estimated in one series (one of every 
three sections in total), in accordance with stereological principles (West, 1993).

For all dLGN measures, preliminary analyses confirmed no significant differences in neuronal dLGN labeling between medial and lateral injections (data not shown). Therefore, data describing retrogradely labeled neurons from medial and lateral injections were averaged within mice rather than being analyzed separately. Two subjects were deemed outliers due to scores $>3$ SDs from the mean and were excluded.

BDNF expression. Using another cohort of mice of the same age range, we evaluated a potential mechanism underlying LI-rTMS by measuring BDNF in the visual cortex and, to confirm previous results (Rodger et al., 2012), the superior colliculus. BDNF expression in the dLGN could not be examined because of the impossibility of precise microdissection of this region. Axons of the optic tract traverse the external surface of the dLGN and are known to transport BDNF (Quigley et al., 2000; Spalding et al., 2002); therefore, any results obtained could not be attributed exclusively to the dLGN. To compare the acute and cumulative effects of LI-rTMS, BDNF levels were measured in mice killed 2 and $24 \mathrm{~h}$ after a single stimulation session and $24 \mathrm{~h}$ after the last session of $14 \mathrm{~d}$ stimulation $(n=8)$. Mice were habituated to handling and the LI-rTMS coil for $4 \mathrm{~d}$ before commencing stimulation or sham. All other aspects of LIrTMS administration were identical to that used in the anatomical experiments. All biochemical procedures were performed blinded to stimulation condition and genotype.

After terminal anesthesia of $0.2 \mathrm{ml}$ of sodium pentobarbitone injected intraperitoneally, visual cortex and superior colliculus samples were rapidly excised and frozen. Samples were stored at $-80^{\circ} \mathrm{C}$ until homogenized in $1 \mathrm{ml}$ of ice-cold lysis buffer (100 mм PIPES, pH 7; $500 \mathrm{~mm} \mathrm{NaCl}$; $0.2 \%$ Triton X-100; $0.1 \% \mathrm{NaN}_{3} ; 2$ mM EDTA; EDTA-free mini protease inhibitors; Roche Diagnostics; Szapacs et al., 2004) and centrifuged $\left(3320 \times g\right.$ for $1 \mathrm{~h}$ at $\left.4^{\circ} \mathrm{C}\right)$. Protein content was determined using the BCA method (BCA protein assay kit; Pierce). The supernatant was analyzed by ELISA for BDNF according to the manufacturer's instructions (ChemiKine BDNF Sandwich ELISA; Millipore Bioscience Research Reagents). Optical absorbance measures $(450 \mathrm{~nm})$ were performed automatically using a spectrophotometer plate reader with EnSpire software (PerkinElmer). BDNF concentration was then calculated as a percentage of total protein for each sample. For comparison between groups, data were normalized to percentage of wild-type-sham within each region.

Statistical analyses. The number of corticotectal TZs per injection was analyzed with Fisher's exact test. Topography was assessed further with linear regression. All other anatomical tracing data were analyzed using two-factor ANOVAs with between-subjects factors: genotype (wild-type, ephrin-A2A $5^{-1-}$ ) and stimulation condition (sham, LI-rTMS). Follow-up post hoc tests with Sidak correction were constrained to comparisons between sham and LI-rTMS within each genotype. Because BDNF expression may not be independent between the visual cortex and superior colliculus within each mouse, group differences combined across the two regions were first analyzed using multivariate ANOVA (MANOVA) to protect against elevated risk of type one error, and then followed up with ANOVAs and Sidak-corrected post hoc tests performed separately for each region. The relationship between BDNF concentration in the visual cortex and superior colliculus was examined using Pearson's correlations and linear regression. The level for significance was set at $p<0.05$. Statistical analyses were performed using GraphPad Prism version 6 and SPSS version 20 software.

\section{Results}

To assess LI-rTMS effects on cortical circuit reorganization, we examined topography of $\mathrm{V} 1$ projections and geniculate afferents using anterograde (corticotectal) and retrograde (geniculocortical) tracing (injection outcomes summarized in Table 1). Mean injection volumes did not differ significantly between groups (ANOVA, all $p>0.05$ ), allowing direct comparison of measurements between experimental groups.
Table 1. Corticotectal injection outcomes

\begin{tabular}{|c|c|c|c|c|}
\hline & \multicolumn{2}{|c|}{ Wild-type } & \multicolumn{2}{|c|}{ Ephrin-A2A5 $^{-1-}$} \\
\hline & Sham & LI-rTMS & Sham & LI-rTMS \\
\hline No. of mice injected & 11 & 11 & 10 & 12 \\
\hline $\begin{array}{l}\text { No. of mice with both injections } \\
\text { successful ( } \% \text { with multiple TZs) } \\
\text { No. of abnormal TZs/no. of successful } \\
\text { injections (\%) }\end{array}$ & $7(0)$ & $7(0)$ & $6(100)$ & $10(88)$ \\
\hline Total & $0 / 18$ & $0 / 18$ & $9 / 16(56)$ & $10 / 21(47)$ \\
\hline Medial & $0 / 7$ & $0 / 8$ & $4 / 7(57)$ & $6 / 10(60)$ \\
\hline Lateral & $0 / 11$ & $0 / 10$ & $5 / 9(56)$ & $4 / 11(36)$ \\
\hline
\end{tabular}

\section{LI-rTMS improves topography of abnormal corticotectal projections in ephrin-A2 $\mathrm{A} 5^{-/-}$mice}

First, we examined the effect of LI-rTMS on cortical efferent projections by analyzing the number of TZs labeled in the corticotectal projection of sham- and LI-rTMS-treated wild-type and ephrin-A2 $\mathrm{A}^{-1-}$ mice. We confirmed that successful V1 injections resulted in a single $\mathrm{TZ}$ in wild-type mice and two TZs in the majority of ephrin-A2A $5^{-1-}$ mice (Table 1 ), indicative of abnormal topography (Fig. 2; Wilks et al., 2010). However, LI-rTMS did not reduce the number of ectopic TZs in ephrin-A5A5 ${ }^{-1-}$ mice (Fisher's exact test, $p=0.99$ ).

To further investigate LI-rTMS effects on corticotectal topography, we mapped the location of corticotectal TZs within the superior colliculus relative to injection location using linear regression analysis (Fig. 3). Consistent with previous results (Triplett et al., 2009; Wilks et al., 2010), wild-types showed a strong, positive relationship between injection site (percentage mediallateral) and TZ location (percentage rostral-caudal; $F_{(1,34)}=$ 9.31, $p=0.004$; Fig. $3 A$ ). However, in ephrin-A2A $5^{-1-}$ mice, when all successful injections and distinct TZs were included in the analysis, this relationship was weak and nonsignificant in both the sham and LI-rTMS groups, suggesting abnormal topography (Fig. 3B). In either genotype, sham and LI-rTMS groups did not separately account for significantly more variance in the regression model than a global best-fit line, showing that there was no significant difference between LI-rTMS and sham (wild-types: $F_{(2,32)}=0.23, p=0.79$; ephrin-A2A5 ${ }^{-1-}$ : $\left.F_{(2,54)}=0.25, p=0.78\right)$.

Because normal and abnormal projections are present in ephrin-A2A $5^{-1-}$ mice and LI-rTMS may affect them differentially, we used regression analysis to identify the least and most disordered TZ in each mouse based on distance from location predicted by injection sites (see Materials and Methods). For the least disordered TZs, there were no significant differences between genotypes or stimulation conditions in mean distance from predicted location (ANOVA; all $p>0.05$; Fig. $4 A$ ). In contrast, the most disordered TZs in ephrin-A2A $5^{-1-}$ mice differed significantly from wild-types in distance from predicted location $\left(F_{(1,26)}=17.25, p<0.001\right)$. However, there was no significant effect of stimulation condition $\left(F_{(1,26)}=2.64, p=0.12\right)$ and no significant interaction $\left(F_{(1,26)}=3.17, p=0.09\right)$. Follow-up tests were conducted despite the nonsignificant main effect of stimulation because, given previous findings in the retinotectal projection (Rodger et al., 2012), we hypothesized that LI-rTMS would affect ephrin-A2A $5^{-1-}$ mice, but not wild-types. Follow-up tests with Sidak correction showed that LI-rTMS significantly decreased disorder compared with sham in the most disordered TZs of ephrin-A2A $5^{-1-}$ mice $(p=0.04)$, but did not affect topography in wild-type mice $(p=0.99)$. In summary, although LIrTMS did not decrease the number of ectopic corticotectal TZs, 


\section{A Sham Wildtype}

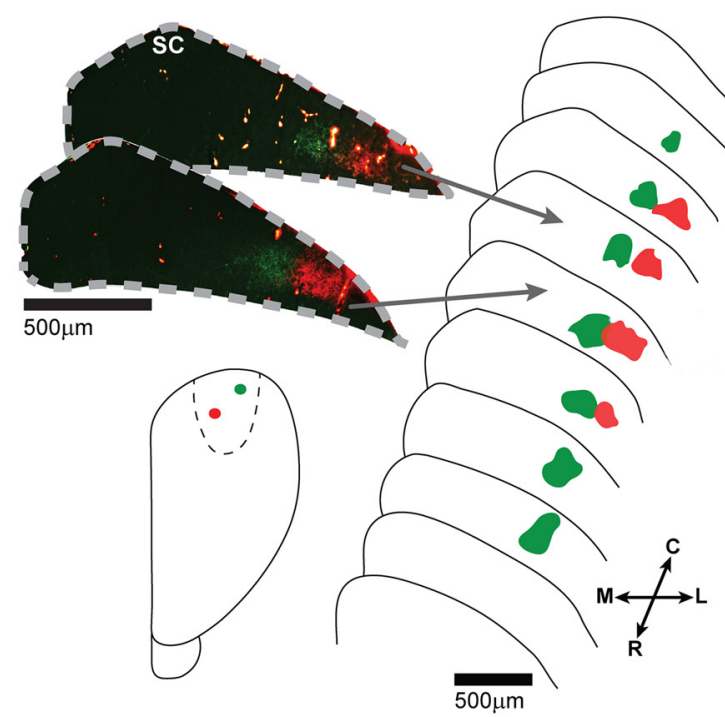

B LI-rTMS Wildtype

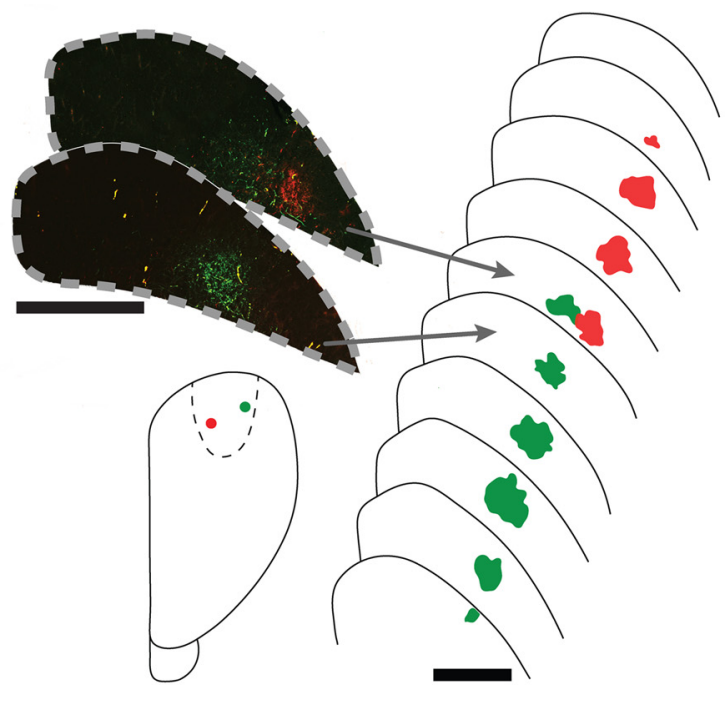

C Sham Ephrin-A2A5--

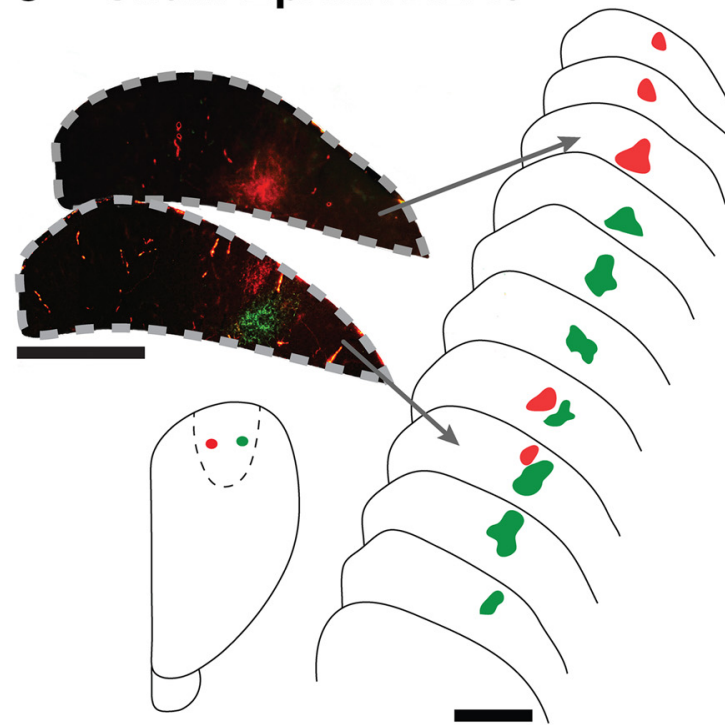

D LI-rTMS Ephrin-A2A5

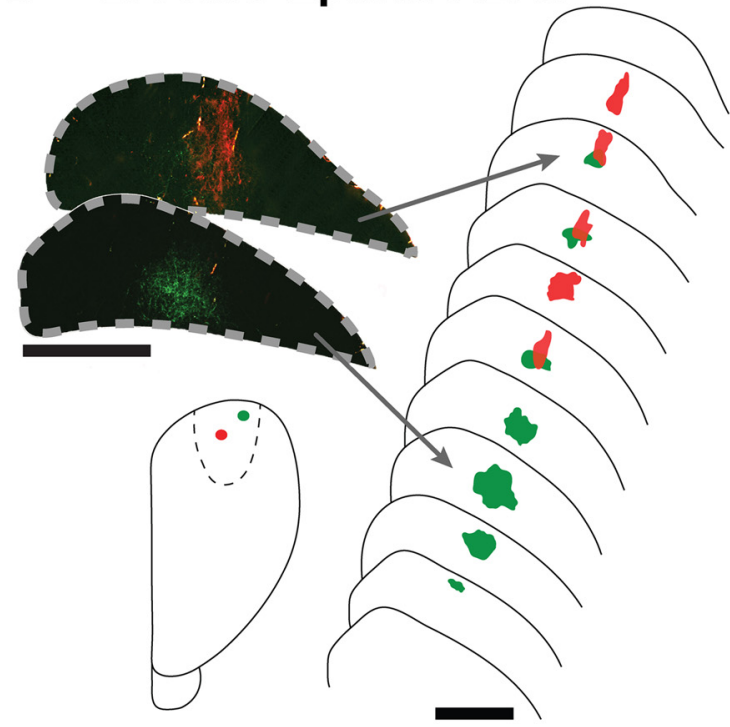

Figure 2. Representative photomicrographs of labeled TZs in the superior colliculus, schematic reconstructions of TZ distribution, and cortical injection sites. Section outlines are separated by 80 $\mu \mathrm{m}$. All wild-types, regardless of receiving sham $(\boldsymbol{A})$ or LI-rTMS (B), displayed a single TZ per injection, with lateral V1 injections (green) labeling a TZ in rostral superior colliculus and medial V1 injections (red) labeling a single TZ located more caudally in the superior colliculus. In contrast, a single cortical injection labeled two TZs in the majority of ephrin-A2A5 ${ }^{-1-}$ mice, although the number of additional TZs was not significantly different between mice receiving sham $(\boldsymbol{C})$ or 14 daily sessions of LI-rTMS (D) (Fisher's exact test, $p=0.99)$. Note that, in $\boldsymbol{C}$, the medial V1 injection (red) labeled two TZs, separated by $360 \mu \mathrm{m}$, whereas the lateral (green) labeled only a single, more rostrally located TZ. In $\mathbf{D}$, the lateral (green) injection labeled two TZs, separated by $120 \mu \mathrm{m}$, and the medial (red) labeled only a single TZ. Photomicrographs were digitally recolored from grayscale images and separate channels merged. R, Rostral; C, caudal; M, medial; L, lateral.

LI-rTMS improved topographic disorder by shifting the most abnormal corticotectal terminals toward a more topographically appropriate location.

All LI-rTMS groups showed slightly greater mean TZ volumes than sham (Fig. 4B), however, this was not significant (all $p>$ 0.05). Consistent with previous reports (Wilks et al., 2010), wildtypes had significantly greater mean $\mathrm{TZ}$ volumes than the most disordered ephrin-A2A5 ${ }^{-1-}$ TZs $\left(F_{(1,26)}=7.97, p=0.01\right)$, but not the least disordered TZs $\left(F_{(1,26)}=2.14, p=0.16\right)$.

LI-rTMS refines abnormal geniculocortical topography in ephrin-A2A $5^{-1-}$ mice

In addition to the structural plasticity of cortical efferent projections, we also evaluated LI-rTMS effects on V1 afferent terminals by quantifying the distribution and number of retrogradely labeled dLGN neurons (Fig. 5).

Consistent with previous reports (Cang et al., 2008), our convex-hull measurements showed that labeled neurons were scattered over a significantly higher percentage of the dLGN in ephrin-A2A $5^{-/-}$mice compared with wild-types, representing greater dispersion $\left(F_{(1,38)}=30.90, p<0.001\right.$; Fig. $\left.5 E\right)$. In addition, LI-rTMS significantly reduced the abnormally high dispersion in ephrin-A2A $5^{-1-}$ mice $(p<0.001)$, but had no significant effect in wild-types $(p=0.95)$. Moreover, the mean area occupied by the main cluster, excluding scattered labeled neurons, remained constant, with no significant differences between groups (ANOVA; all $p>0.05$; Fig. $5 F$ ). Therefore, our data sug- 

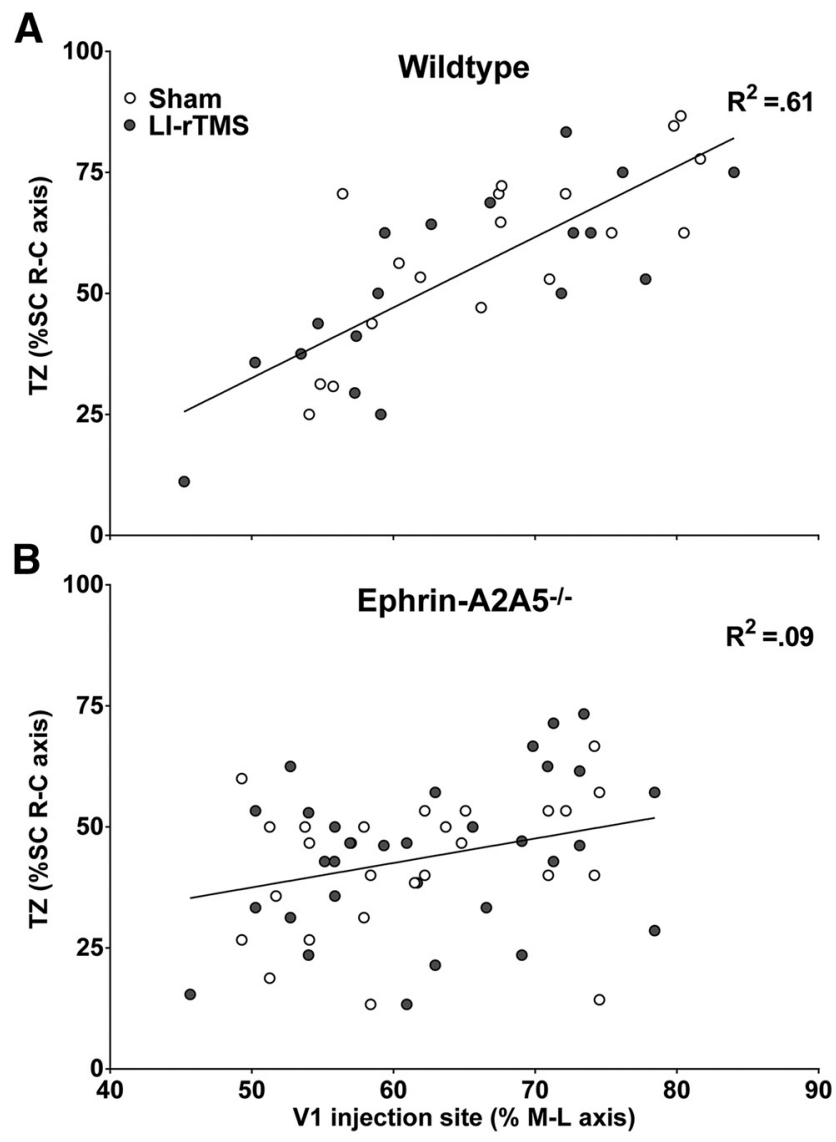

Figure 3. Corticotectal TZ locations as a percentage of the superior colliculus rostral-caudal $(\mathrm{R}-\mathrm{C})$ axis are plotted as a function of $\mathrm{V} 1$ injection site location, as a percentage of the cortical hemisphere medial-lateral (M-L) axis. In wild-types ( $A)$, V1 injection location (percentage $M-L$ ) strongly and significantly predicted corticotectal TZ location (R-C axis). For ephrin-A2A5 ${ }^{-1-}$ mice $(\boldsymbol{B})$, analyzing all TZs and successful injections together, V1 injection (percentage $\mathrm{M}-\mathrm{L}$ ) did not significantly predict TZ locations in the superior colliculus (SC) R-C axis and the relationship was weak. There was no significant difference between LI-rTMS and sham for either genotype. Lines represent linear best-fit regression.

gest that LI-rTMS selectively affected topographically inappropriate geniculocortical afferents.

Further supporting LI-rTMS-induced reorganization of abnormal geniculocortical afferents in ephrin-A2A $5^{-1-}$ mice, there were significant effects of stimulation condition and genotype on the number of labeled dLGN neurons (stimulation condition: $F_{(1,38)}=6.01, p=0.01$; genotype: $F_{(1,38)}=9.27, p=0.004$; Fig. $5 G)$. Although post hoc tests were nonsignificant, there was a strong trend for LI-rTMS to reduce the number of labeled neurons compared with sham-treated ephrin-A2A $5^{-1-}$ mice (Sidak correction: $p=0.07)$. This trend was not observed for wild-types $(p=0.40)$.

\section{LI-rTMS increases BDNF concentration}

To investigate a possible molecular mechanism for LI-rTMSinduced structural reorganization, we compared BDNF concentrations in the visual cortex and superior colliculus between sham- and LI-rTMS-treated mice. To distinguish between acute and cumulative effects, we measured BDNF after a single stimulation session ( 2 and $24 \mathrm{~h}$ after stimulation) and 14 daily sessions. Consistent with previous studies (Kuczewski et al., 2008), BDNF levels were in picogram amounts. Analysis was conducted relative to total protein in the sample and relative to wild-type sham controls (see Materials and Methods).
Because BDNF is anterogradely transported from visual cortex to superior colliculus (Conner et al., 1997), its expression in each region cannot be considered independent. Therefore, we used MANOVA (Pillai's trace) to analyze group differences combined across the two regions, which showed a significant effect of LI-rTMS time point on BDNF concentrations in the visual cortex and superior colliculus $\left(V=0.96, F_{(6,112)}=17.16, p<0.001\right)$. Subsequent two-factor ANOVAs, conducted separately for the visual cortex and superior colliculus, showed that BDNF concentration differed significantly between genotypes (visual cortex: $F_{(1,56)}=7.87, p=0.007$; superior colliculus: $F_{(1,56)}=31.75, p<$ 0.0001 ) and LI-rTMS time points (visual cortex: $F_{(3,56)}=20.79$, $p<0.001$; superior colliculus: $\left.F_{(3,56)}=20.68, p<0.0001\right)$. There was also a significant interaction in both regions (visual cortex: $F_{(3,56)}=3.69, p=0.02$; superior colliculus: $F_{(3,56)}=10.49, p<$ $0.0001)$, indicating that wild-type and ephrin-A2A $5^{-1-}$ mice responded differently at specific LI-rTMS time points. In wildtypes, LI-rTMS acutely increased BDNF levels in both the visual cortex (Fig. 6A) and the superior colliculus (Fig. 6B) compared with sham $(2 \mathrm{~h}, p<0.001 ; 24 \mathrm{~h}, p<0.01)$, but these increases were not sustained after $14 \mathrm{~d}$ of stimulation $(p=0.99)$. In contrast, in ephrin-A2A $5^{-/-}$mice, BDNF expression increased significantly in the visual cortex only at $24 \mathrm{~h}$ after a single stimulation session $(p=0.02)$ and was not sustained after 14 daily stimulation sessions $(p=0.19)$, whereas in the superior colliculus of ephrin-A2A $5^{-1-}$ mice, BDNF expression was significantly greater compared with sham for all LI-rTMS time points (all $p<0.0001$; Fig. 6B).

Finally we tested whether the raised collicular BDNF might arise from cortical synthesis and transport (i.e., BDNF produced in visual cortex may be transported to the superior colliculus, resulting in lower levels in visual cortex and correspondingly higher levels in the superior colliculus) through correlation analyses between visual cortex and superior colliculus BDNF concentrations at each time point (Fig. $6 C-F$ ). There were no significant correlations (all $p>0.05$ ) and most correlations were weak, suggesting that transport between regions is unlikely to contribute to BDNF concentration as strongly as local production and/or transport from other regions (e.g., retina; Conner et al., 1997; Quigley et al., 2000; Spalding et al., 2002).

\section{Discussion}

We used both normal and abnormal mouse visual systems to investigate the effects of low-intensity magnetic stimulation on neural circuits. We present the first direct evidence that LI-rTMS induces structural reorganization across multiple relays within the visual network (Fig. 7). Our data suggest that differential BDNF signaling in visual cortex and superior colliculus may underlie LI-rTMS reorganization of abnormal neural circuits. Furthermore, the low intensity of our stimulation suggests that induced spiking activity may not be a prerequisite for magnetic stimulation effects. Together, our results suggest that LI-rTMS, and possibly rTMS clinically, may reinitiate some aspects of the developmental critical period that are permissive for neuroanatomical reorganization.

\section{LI-rTMS affects multiple relays of the visual pathway: parallels with development}

Human studies demonstrate that rTMS effects extend beyond the targeted region and affect interconnected pathways (Reithler et al., 2011). Consistent with this, we observed reorganization after LIrTMS in three interconnected visual pathways: the retinotectal (Rodger et al., 2012), corticotectal, and geniculocortical projections. Moreover, the changes that we observed in these three circuits are 
A
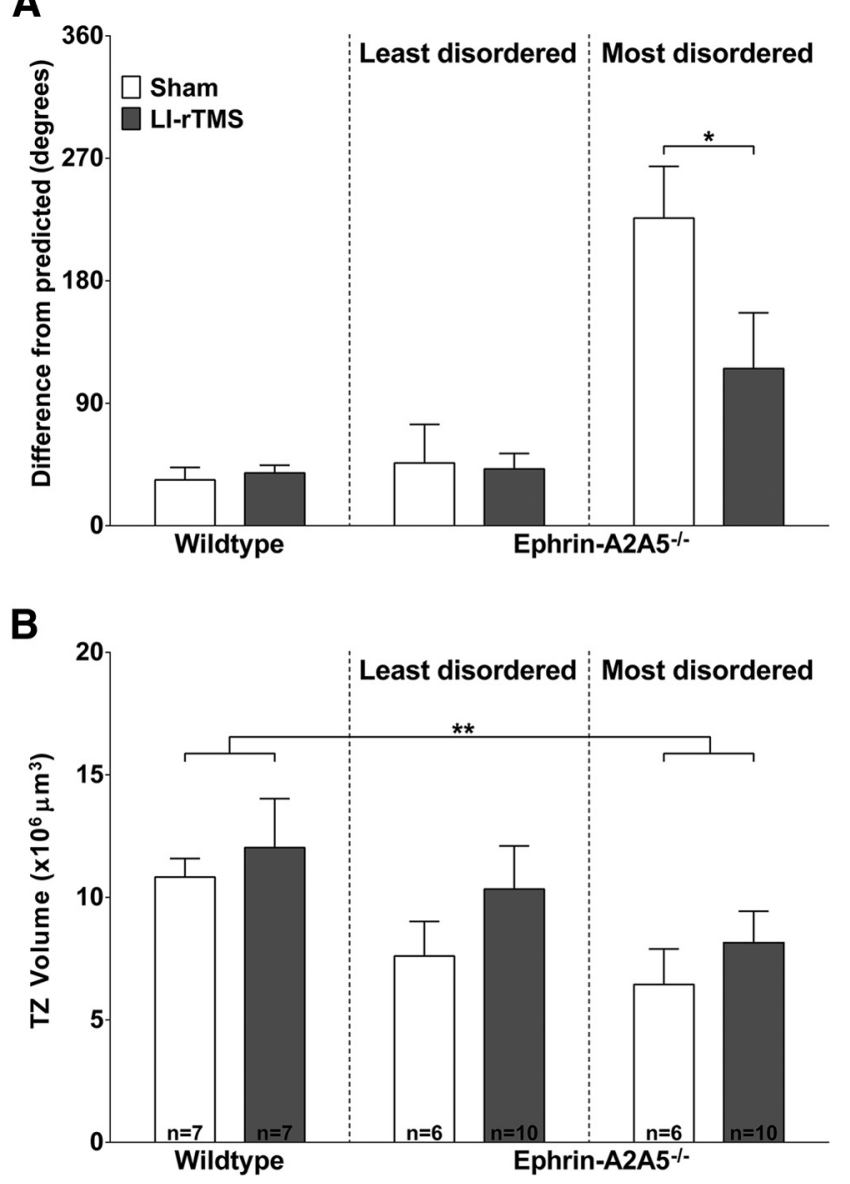

Figure 4. LI-rTMS reduces extent of corticotectal topographical disorder in ephrinA2A5 ${ }^{-1-}$ mice. $A$, Mean difference between TZ locations from that predicted by injection sites, with wild-types and the least disordered and most disordered TZ pairs within ephrin-A2A5 ${ }^{-1-}$ mice shown separately. LI-rTMS significantly reduced the disorder of the most disordered TZs. $\boldsymbol{B}$, Mean volume of TZs in wild-type and ephrin-A2A5 ${ }^{-1-}$ mice, with wild-types and the least disordered and most disordered TZ pairs within ephrin-A2A5 ${ }^{-1-}$ mice shown separately. TZ volume was not significantly different between ephrin-A2A5 ${ }^{-1-}$ and wild-type mice for the least disordered TZs. However, the most disordered TZs were significantly smaller compared with wild-types. There was no significant effect of LI-rTMS on TZ volume. ${ }^{*} p<0.05$.

reminiscent of visual system development (McLaughlin and O'Leary, 2005). Therefore, our finding that LI-rTMS induces structural reorganization in adult mice that are beyond the classical critical period for visual system map formation (Inoue et al., 1992) suggests that LI-rTMS may reactivate developmental processes (Cline, 2003; McLaughlin et al., 2003; McLaughlin and O'Leary, 2005).

A likely mechanism for such plasticity is the upregulation of BDNF induced by magnetic stimulation (present study; Gersner et al., 2011; Rodger et al., 2012). During development, closure of the critical period is associated with downregulation of BDNF (Huang et al., 1999). Furthermore, increased BDNF within the mature visual system, whether induced pharmacologically or behaviorally through environmental enrichment, reactivates critical period-like plasticity and reorganization of visual cortical afferents (Mandolesi et al., 2005; Sale et al., 2007; Maya Vetencourt et al., 2008; Baroncelli et al., 2010). Although it is unclear how strongly BDNF contributes to behavioral improvements in the visual system or other brain regions, dark-reared mice displayed normal visual cortical topography after injection with BDNF, suggesting that BDNF alone may be sufficient to reorga- nize visual cortical circuits during development (Gianfranceschi et al., 2003). However, work in adult systems suggests that, although BDNF may be a prerequisite for plastic change (Berardi et al., 1999), functionally useful reorganization may also require coordinated neural activity that is achievable with behavioral training (Sale et al., 2007; Sale et al., 2009). Therefore, LI-rTMS, in conjunction with behavioral training, could be a useful adjuvant therapy for rehabilitation.

In addition, reactivation of developmental processes could also facilitate interactions between retinotectal and corticotectal maps. In the developing visual system, retinotectal topography is established first within the superior colliculus, and the later developing corticotectal map partly depends on the retinotectal map for its organization (Triplett et al., 2009). It is therefore possible that LI-rTMS-induced reorganization within the retinotectal projection (Rodger et al., 2012) may contribute to, or even drive, the shift of corticotectal terminals. Therefore, developmental mechanisms, reminiscent of the critical period, may underlie LI-rTMS-induced visual pathway reorganization.

\section{LI-rTMS selectively affects abnormal projections}

Within the visual network, reorganization by LI-rTMS is not uniform; our data show that LI-rTMS preferentially induces plasticity in abnormal cortical circuits. This finding is consistent with animal studies (Valero-Cabré et al., 2008; Rodger et al., 2012; Sykes et al., 2013) and human studies showing null or transient stimulation effects in healthy participants, but longer-term effects in clinical populations (Siebner et al., 2004; Capone et al., 2009; Martiny et al., 2010). Disrupted homeostatic plasticity in abnormal systems may interact with BDNF signaling (Desai et al., 1999), enabling LI-rTMS to affect abnormal circuits selectively. Subthreshold changes to membrane potential, such as those induced by LI-rTMS, upregulate BDNF expression (Zafra et al., 1990; Singh and Miller, 2005; Pell et al., 2011) and may contribute to the initial increase in BDNF for all groups. However, in normal systems, such excitation also triggers homeostatic mechanisms (e.g., GABA-A receptor activation) that downregulate BDNF (Berninger et al., 1995), consistent with wild-types showing no change in BDNF after $14 \mathrm{~d}$ of stimulation. In contrast, in ephrin$\mathrm{A} 2 \mathrm{~A} 5^{-1-}$ mice, competition between ectopic and appropriately located terminals is likely to perturb homeostatic plasticity (Cao et al., 2007). Therefore, in the superior colliculus, where cortical efferent ectopic terminals are retained, albeit more accurately located, the stimulus for upregulation of BDNF is sustained. In contrast, in the visual cortex, geniculocortical errors in ephrin$\mathrm{A} 2 \mathrm{~A} 5^{-1-}$ mice are less severe than corticotectal abnormalities (Wilks et al., 2010) and were effectively corrected by LI-rTMS; therefore, the transient BDNF increase in the visual cortex, which returned to baseline by $14 \mathrm{~d}$, may reflect normal homeostatic downregulation of BDNF (Huang et al., 1999).

BDNF also modulates growth cone response to axonal guidance cues, including semaphorins and Eph/ephrins (Fitzgerald et al., 2008; Marler et al., 2008; Marler et al., 2010; Naska et al., 2010); therefore, LI-rTMS-induced upregulation of BDNF may promote appropriate circuit reorganization by increasing sensitivity to environmental cues. Our findings linking LI-rTMSinduced structural reorganization to BDNF expression are compatible with long-term behavioral modifications in healthy (Valero-Cabré et al., 2008) and parietally injured (Afifi et al., 2013) cats. In addition, our findings suggest a mechanism to explain the clinical efficacy of low-intensity magnetic stimulation, as well as rTMS, in disorders associated with plasticity and BDNF abnormalities (Thickbroom and Mastaglia, 2009; Autry 
A Sham Wildtype

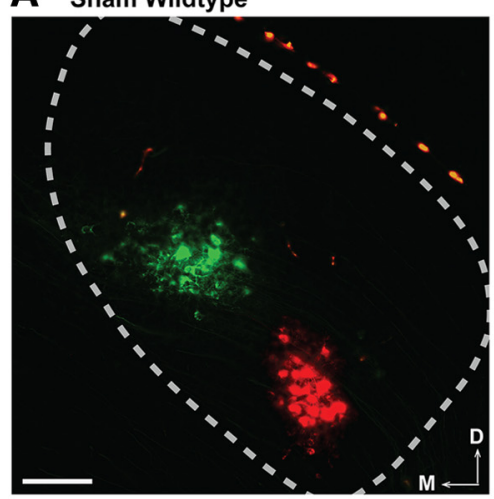

C Sham Ephrin-A2A5/-

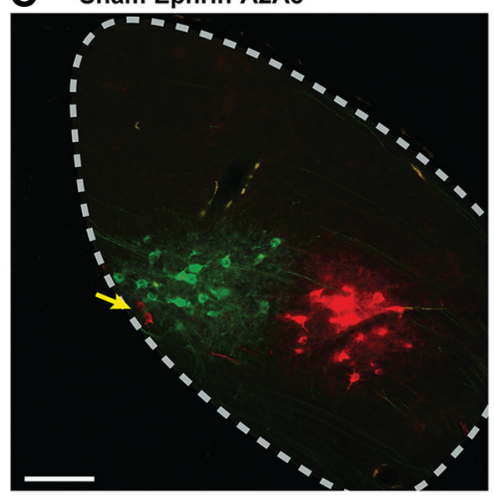

E

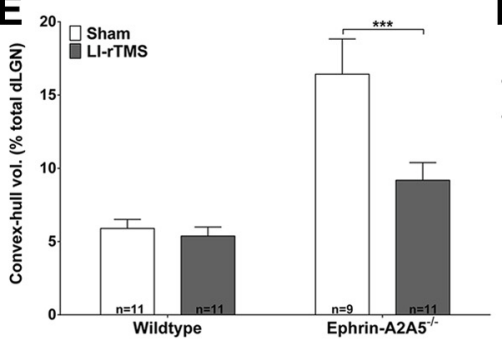

$\mathbf{G}_{45}$

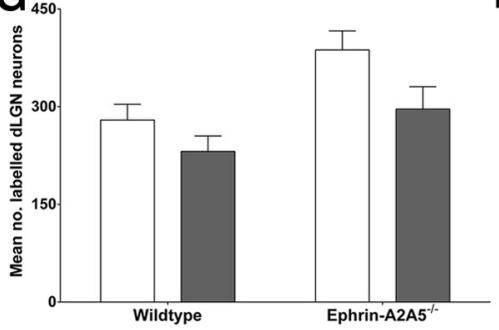

B LI-rTMS Wildtype

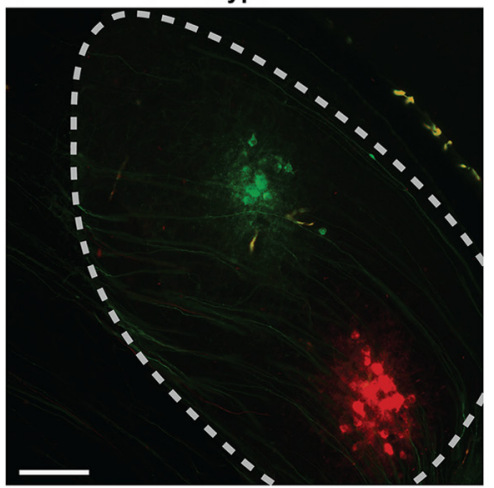

D LI-rTMS Ephrin-A2A5/-

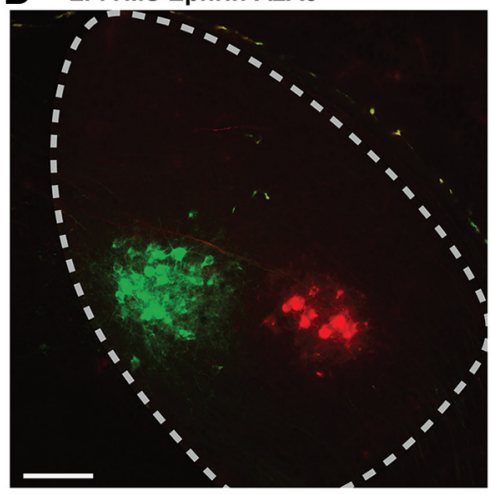

F

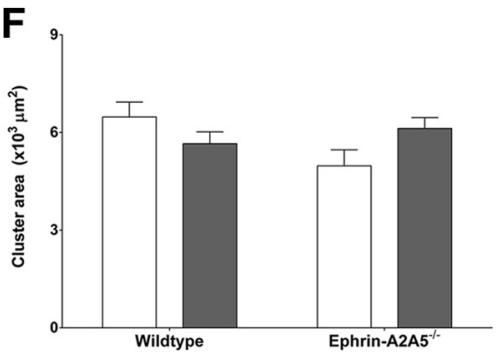

H

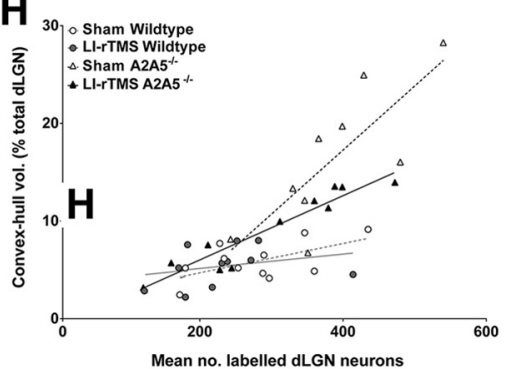

Figure 5. LI-rTMS effects on retrograde labeling of the geniculocortical projection. $\boldsymbol{A}-\boldsymbol{D}$, Photomicrographs of retrogradely labeled neurons in the dLGN from a representative mouse of each genotype and stimulation condition. Cortical injections labeled a main cluster for all groups, suggesting largely normal geniculocortical topography. Note that wild-types in sham (A) and after 14 daily sessions of complex-waveform LI-rTMS $(\boldsymbol{B})$ show similarly few neurons labeled outside the main cluster and similar cluster size, whereas the sham-treated ephrin-A2A5 ${ }^{-1-}$ mouse $(\boldsymbol{C})$ shows labeled cells scattered across a larger area compared with the LI-rTMS-treated ephrin-A2A5 ${ }^{-1-}$ mouse $(\boldsymbol{D})$ or wild-types $(\boldsymbol{A}, \boldsymbol{B})$. The yellow arrow indicates two red cells separated from the main red cluster, illustrating broad scatter of labeled neurons in the sham-treated ephrin-A2A5 ${ }^{-1-}$ mouse. Photomicrographs were digitally recolored from grayscale images and separate channels merged. Scale bars, $100 \mu \mathrm{m}$. E, Quantification of retro gradely labeled cell dispersion in the dLGN. The mean percentage of the total dLGN volume occupied by the convex-hull (in cubic micrometers), defined by the volume of straight lines joining the outermost labeled cells, was greatest in sham-treated ephrin-A2A $5^{-1-}$ mice and decreased with LI-rTMS; in wild-types, dispersion was similar between sham and LI-rTMS. F, Mean labeled neuron cluster area (in square micrometers) in the dLGN was similar between all groups. G, Mean number of labeled dLGN neurons. LI-rTMS decreased the number of labeled cells in both genotypes, although the magnitude of this decrease was greater in ephrin-A2A5 ${ }^{-I-}$ mice than in wild-types. Error bars indicate SEM. $\boldsymbol{H}$, Cell dispersion (convex-hull volume as percentage total dLGN volume) as a function of total number of labeled dLGN neurons. Note that although sham-treated ephrin-A2A5 ${ }^{-1-}$ mice had somewhat more labeled neurons compared with other groups, at any given number of labeled neurons, dispersion tended to be greater in sham-treated ephrin-A2A $5^{-1-}$ mice than other groups. Lines represent linear best-fit regression. $A 2 A 5^{-I-}$, Ephrin-A2A5 ${ }^{-l-}$ mice; $D$, dorsal; $M$, medial. ${ }^{* * *} p<0.001$. 
A

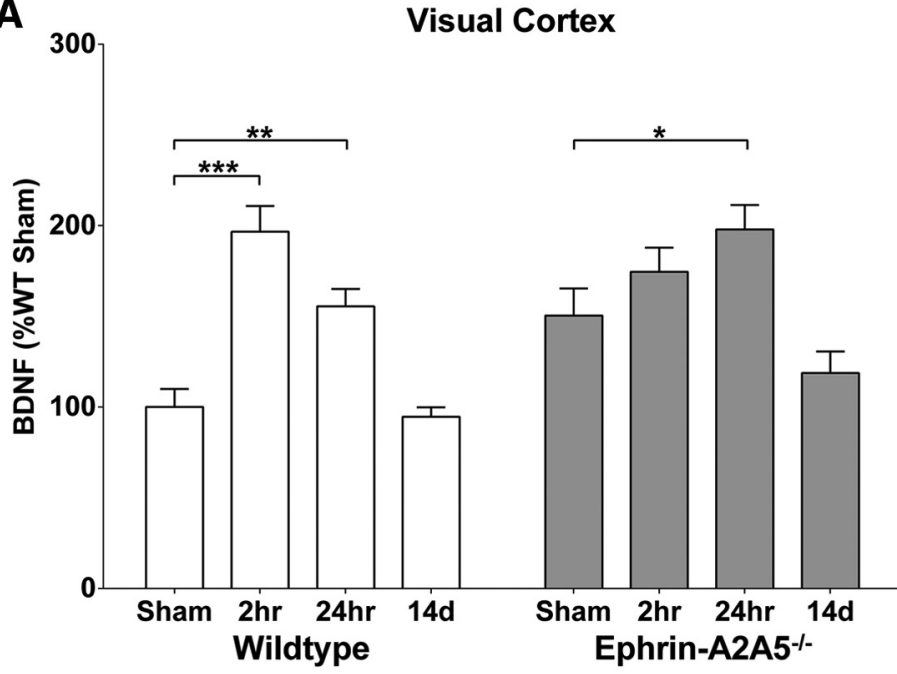

C

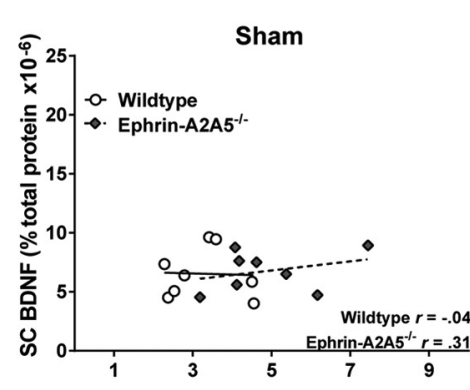

D

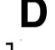

B

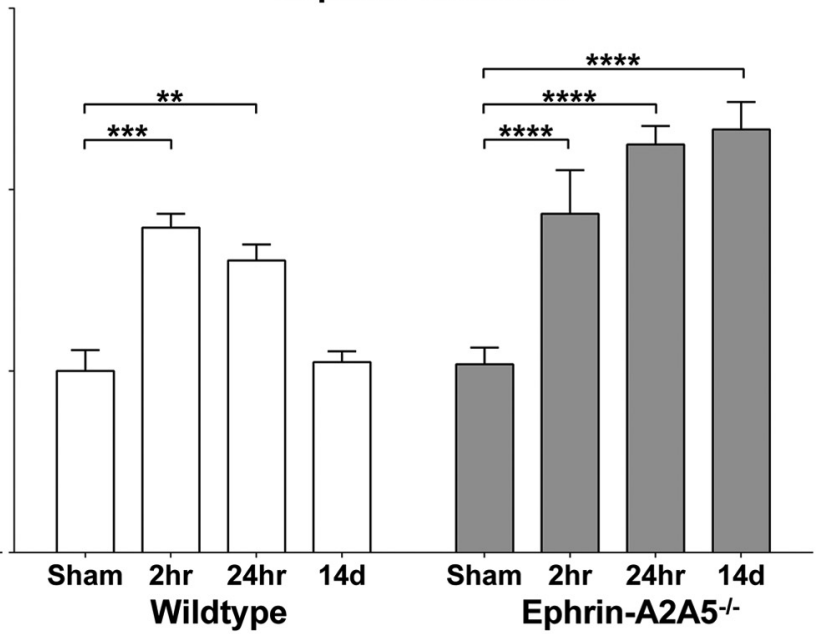

Superior Colliculus

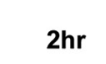

E

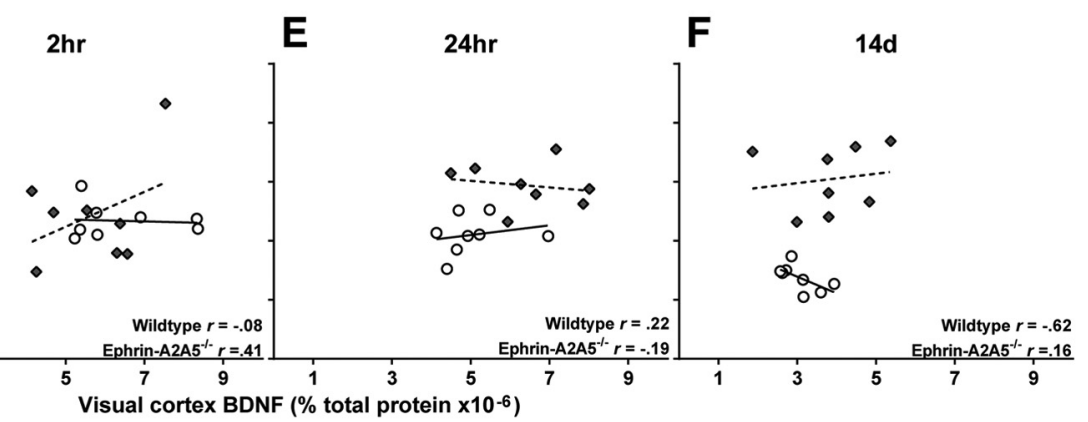

F

$14 d$

Figure 6. BDNF concentrations in ephrin-A2A5 ${ }^{-1-}$ and wild-type mice, contrasting control, single, and multiple LI-rTMS session groups. BDNF concentration, normalized to percentage of wild-type sham, in visual cortex $(\boldsymbol{A})$ and superior colliculus $(\boldsymbol{B}) 2$ and $24 \mathrm{~h}$ after a single LI-rTMS session and after $14 \mathrm{~d}$ of daily LI-rTMS (24 h after final stimulation) are compared with sham (no stimulation control). $\mathbf{C}-\boldsymbol{F}$, Scatterplots of BDNF concentration (as percentage of total protein) between visual cortex and superior colliculus shown separately for each genotype and stimulation time point. All correlations were nonsignificant. Lines represent linear best-fit. ${ }^{*} p<0.05 ;{ }^{* *} p<0.01 ;{ }^{* * *} p<0.001 ;{ }^{* * *} p<0.0001$.

and Monteggia, 2012; low intensity: Prato et al., 2005; Martiny et al., 2010; rTMS: Wassermann and Zimmermann, 2012).

\section{Projection-specific effects of LI-rTMS may reflect multiple mechanisms of action}

In addition to acting primarily on the abnormal visual circuits, a key result of our study is that LI-rTMS corrects topographical errors differently within specific components of the visual circuit, suggesting different mechanisms. A possible explanation is that BDNF has different effects on axonal terminals depending whether signaling occurs via TrkB or $\mathrm{p} 75^{\mathrm{NTR}} /$ Troy (Schecterson and Bothwell, 2010), suggesting that the differential expression of these receptors throughout the visual circuit may determine whether abnormal projections are moved or eliminated. In contrast to our previous work in the retinotectal pathway of ephrinA2A ${ }^{-1-}$ mice, where LI-rTMS removed ectopic terminals (Rodger et al., 2012), here, we show that abnormal corticotectal projections are retained but moved to more topographically appropriate locations. Although LI-rTMS upregulated BDNF in the superior colliculus of ephrin-A2A $5^{-1-}$ mice, where both projections converge (Sefton et al., 2004), the different outcomes in these pathways may be due to regional differences in neurotrophin receptor expression. In the retinotectal projection, high p75 NTR/Troy in retinal ganglion cells (Ugolini et al., 1995; Park et al., 2005), together with low TrkB expression (Rickman and Brecha, 1995), would promote ectopic terminal elimination (Singh et al., 2008; Sherrard et al., 2009). In contrast, corticotectal axons coexpress TrkB and p75 ${ }^{\text {NTR }}$ (McQuillen et al., 2002), allowing the higher affinity of BDNF for TrkB to promote reorganization, rather than removal, of ectopic corticotectal terminals (Bibel et al., 1999; Majdan and Miller, 1999). We also show plasticity in the geniculocortical projection of ephrin-A2A $5^{-1-}$ mice after transient upregulation of BDNF. Geniculocortical neurons express TrkB without $\mathrm{p} 75^{\mathrm{NTR}}$ (Silver and Stryker, 2001; McQuillen et al., 2002); withdrawal of TrkB signaling after a period of transient activation results in axon retraction (Luikart and Parada, 2006; Sherrard et al., 2009). This suggests that the reduced dLGN cell dispersion we observed after LI-rTMS is due to removal, rather than reorganization, of aberrant geniculocortical terminals. Our present results do not allow causal relationships to be established between BDNF signaling and LI-rTMS-induced reorganization across the different relays of the visual pathway; future research could address this interesting issue through lesion studies and analysis of behavioral performance.

Projection-specific effects may also be due to differences in magnetic field intensities delivered across the brain (Cohen et al., 1990; Deng et al., 2013). Visual brain regions received stimulation synchronously but at different intensities: V1 and superior colliculus are in close proximity in the mouse brain (Figs. 1,7) and received similar intensities $(6-8 \mathrm{mT})$, but the $\mathrm{dLGN}$ received $\sim 2 \mathrm{mT}$ and the retina $<1 \mathrm{mT}$ (Rodger et al., 2012). Given that human studies show different immediate excitability changes depending on stimulation intensity (Kähkönen et al., 2005; Batsikadze et al., 2013), these differences in field strength across the visual pathway could contribute to the different patterns of reorganization after LI-rTMS: terminal elimination within the weakly stimulated retinotectal (Rodger et al., 2012) 


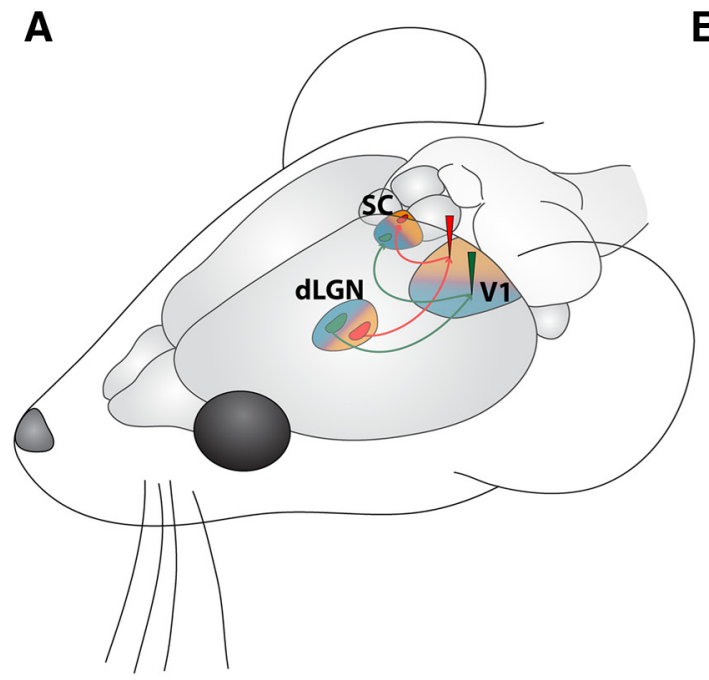

B

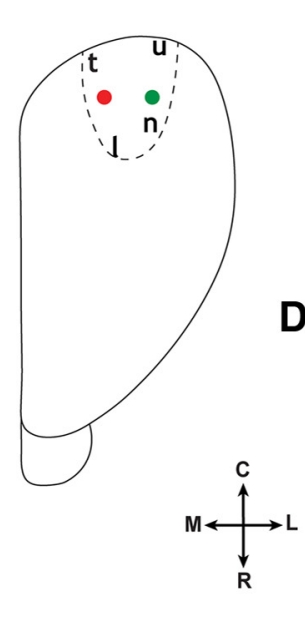

C sc

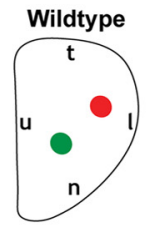

dLGN

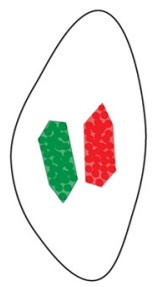

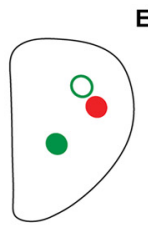

Ephrin-A2A5-1-

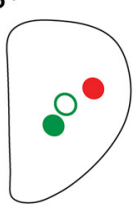

LI-rTMS
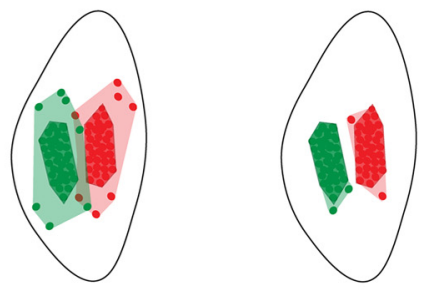

Figure 7. Summary of topographical reorganization effects of LI-rTMS. A, Schematic diagram illustrating appropriate topographic projections of the corticotectal (efferent) and geniculocortical (afferent) projections from medial (red) and lateral (green) locations in V1. Shading represents nasal (blue) and temporal (orange) visual field maps for each region. Arrows indicate direction of visual information flow. $\boldsymbol{B}$, Dorsal view of the visual cortex showing injection sites. $\boldsymbol{C}, \boldsymbol{D}$, Dorsal view of characteristic labeling in superior colliculus (C) and dLGN (D) resulting from injections shown in $\boldsymbol{B}$ for wild-type and ephrin-A2A5 ${ }^{-1-}$ mice. After LI-rTMS (far right), ephrin-A2A5 ${ }^{-1-}$ mice showed a shift of ectopic terminal zones (open circles) toward a more topographically appropriate location in the superior colliculus, whereas the appropriate TZs (filled circles) were unaffected (C). In the dLGN, ephrin-A2A5 ${ }^{-1-}$ mice showed decreased labeled cell dispersion (D) —-that is, a smaller convex hull volume (pale shading) — whereas the main labeled cell cluster (dark-shaded area) size remained the same. SC, Superior colliculus; $R$, rostral; $C$, caudal; M, medial; L, lateral; for the following, orientation refers to visual field: $n$, nasal; $t$, temporal; $u$, upper; l, lower.

and geniculocortical projections, but reorganization within the more strongly stimulated corticotectal projection.

\section{Potential mechanisms underlying effects of low-intensity magnetic stimulation}

Our LI-rTMS stimulation was subthreshold, estimated to be 0.5 $\mathrm{V} / \mathrm{m}$ (Martiny et al., 2010), which is several orders of magnitude below the $\sim 50 \mathrm{~V} / \mathrm{m}$ that depolarizes neurons (Volz et al., 2013). Therefore, our data show for the first time that circuit reorganization can occur in the absence of induced spiking activity, which is thought to be the primary mechanism underlying rTMS network effects (Thickbroom, 2007; Benali et al., 2011; Volz et al., 2013). Such network changes in the absence of induced neuronal firing is consistent with the frequency-specific changes to EEG waves reported for very-low-intensity magnetic stimulation (Di Lazzaro et al., 2013). Although mechanisms remain poorly understood, modeling studies indicate that stimulation at intensities used here can alter ion transfer across cell membranes, causing subthreshold changes to membrane potential (Poo, 1981). These subthreshold changes can have lasting effects on neuron activity by opening ion channels, modifying excitability and calcium signaling (Yu et al., 2010; Grehl et al., 2011). In addition, subthreshold presynaptic inputs modulate postsynaptic activity (Alle and Geiger, 2006; Shu et al., 2006). Therefore, transsynaptic modulation may underlie the plastic reorganization that we observed across multiple relays within the visual pathway after LI-rTMS.

Our data suggest mechanisms that may underpin the therapeutic effects of very low-intensity fields described in human studies (Capone et al., 2009; Martiny et al., 2010; Di Lazzaro et al., 2013). In addition, because we show that low-intensity pulsed magnetic fields of similar intensity to those delivered outside of the focal area of stimulation in human rTMS (Wagner et al., 2009) affects neuronal circuits, our study may have implications for understanding mechanisms underlying rTMS clinical effects. However, because our device delivers very different stimulation parameters compared with those typically used in human rTMS/
TMS (Wagner et al., 2009; Pell et al., 2011), our data should not be extrapolated directly to a clinical context.

\section{Conclusions}

In summary, we show that multiple sessions of low-intensity, complex waveform magnetic stimulation induced structural reorganization, improving topographical accuracy in abnormal cortical circuits. Our results suggest that LI-rTMS may prime neuronal circuits via upregulation of BDNF, maintaining a plastic environment conducive to beneficial reorganization. Therefore, this study reveals the power of applying magnetic field stimulation, even at low intensities, to abnormal or dysfunctional neural circuits to correct structural and functional errors.

\section{References}

Afifi L, Jarrett Rushmore R, Valero-Cabré A (2013) Benefit of multiple sessions of perilesional repetitive transcranial magnetic stimulation for an effective rehabilitation of visuospatial function. Eur J Neurosci 37:441454. CrossRef Medline

Alle H, Geiger JR (2006) Combined analog and action potential coding in hippocampal mossy fibers. Science 311:1290-1293. CrossRef Medline

Arias-Carrión O, Verdugo-Díaz L, Feria-Velasco A, Millán-Aldaco D, Gutiérrez AA, Hernández-Cruz A, Drucker-Colín R (2004) Neurogenesis in the subventricular zone following transcranial magnetic field stimulation and nigrostriatal lesions. J Neurosci Res 78:16-28. CrossRef Medline

Arnsten AF, Rubia K (2012) Neurobiological circuits regulating attention, cognitive control, motivation, and emotion: disruptions in neurodevelopmental psychiatric disorders. J Am Acad Child Adolesc Psychiatry 51: 356-367. CrossRef Medline

Autry AE, Monteggia LM (2012) Brain-derived neurotrophic factor and neuropsychiatric disorders. Pharmacol Rev 64:238-258. CrossRef Medline

Aydin-Abidin S, Trippe J, Funke K, Eysel UT, Benali A (2008) High- and low-frequency repetitive transcranial magnetic stimulation differentially activates c-Fos and zif268 protein expression in the rat brain. Exp Brain Res 188:249-261. CrossRef Medline

Baroncelli L, Sale A, Viegi A, Maya Vetencourt JF, De Pasquale R, Baldini S, Maffei L (2010) Experience-dependent reactivation of ocular dominance plasticity in the adult visual cortex. Exp Neurol 226:100-109. CrossRef Medline 
Batsikadze G, Moliadze V, Paulus W, Kuo MF, Nitsche MA (2013) Partially non-linear stimulation intensity-dependent effects of direct current stimulation on motor cortex excitability in humans. J Physiol 591:1987-2000. CrossRef Medline

Benali A, Trippe J, Weiler E, Mix A, Petrasch-Parwez E, Girzalsky W, Eysel UT, Erdmann R, Funke K (2011) Theta-burst transcranial magnetic stimulation alters cortical inhibition. J Neurosci 31:1193-1203. CrossRef Medline

Berardi N, Lodovichi C, Caleo M, Pizzorusso T, Maffei L (1999) Role of neurotrophins in neural plasticity: what we learn from the visual cortex. Restor Neurol Neurosci 15:125-136. Medline

Berninger B, Marty S, Zafra F, da Penha Berzaghi M, Thoenen H, Lindholm D (1995) GABAergic stimulation switches from enhancing to repressing BDNF expression in rat hippocampal neurons during maturation in vitro. Development 121:2327-2335. Medline

Bibel M, Hoppe E, Barde YA (1999) Biochemical and functional interactions between the neurotrophin receptors trk and p75NTR. EMBO J 18: 616-622. CrossRef Medline

Butz M, Wörgötter F, van Ooyen A (2009) Activity-dependent structural plasticity. Brain Res Rev 60:287-305. CrossRef Medline

Cang J, Niell CM, Liu X, Pfeiffenberger C, Feldheim DA, Stryker MP (2008) Selective disruption of one cartesian axis of cortical maps and receptive fields by deficiency in ephrin-As and structured activity. Neuron 57:511523. CrossRef Medline

Cao L, Dhilla A, Mukai J, Blazeski R, Lodovichi C, Mason CA, Gogos JA (2007) Genetic modulation of BDNF signaling affects the outcome of axonal competition in vivo. Curr Biol 17:911-921. CrossRef Medline

Capone F, Dileone M, Profice P, Pilato F, Musumeci G, Minicuci G, Ranieri F, Cadossi R, Setti S, Tonali PA, Di Lazzaro V (2009) Does exposure to extremely low frequency magnetic fields produce functional changes in human brain? Journal of Neural Transmission 116:257-265. CrossRef Medline

Cline H (2003) Sperry and Hebb: oil and vinegar? Trends Neurosci 26:655661. CrossRef Medline

Cohen LG, Roth BJ, Nilsson J, Dang N, Panizza M, Bandinelli S, Friauf W, Hallett M (1990) Effects of coil design on delivery of focal magnetic stimulation: technical considerations. Electroencephalogr Clin Neurophysiol 75:350-357. CrossRef Medline

Conner JM, Lauterborn JC, Yan Q, Gall CM, Varon S (1997) Distribution of brain-derived neurotrophic factor (BDNF) protein and mRNA in the normal adult rat CNS: Evidence for anterograde axonal transport. J Neurosci 17:2295-2313. Medline

Cook CM, Thomas AW, Prato FS (2004) Resting EEG is affected by exposure to a pulsed ELF magnetic field. Bioelectromagnetics 25:196-203. CrossRef Medline

Deng ZD, Lisanby SH, Peterchev AV (2013) Electric field depth-focality tradeoff in transcranial magnetic stimulation: simulation comparison of 50 coil designs. Brain Stimulation 6:1-13. CrossRef Medline

Desai NS, Rutherford LC, Turrigiano GG (1999) BDNF regulates the intrinsic excitability of cortical neurons. Learn Mem 6:284-291. Medline

Di Lazzaro V, Capone F, Apollonio F, Borea PA, Cadossi R, Fassina L, Grassi C, Liberti M, Paffi A, Parazzini M, Varani K, Ravazzani P (2013) A consensus panel review of central nervous system effects of the exposure to low-intensity extremely low-frequency magnetic fields. Brain Stimul 6:469-476. CrossRef Medline

Dorr A, Sled JG, Kabani N (2007) Three-dimensional cerebral vasculature of the CBA mouse brain: A magnetic resonance imaging and micro computed tomography study. Neuroimage 35:1409-1423. CrossRef Medline

Epstein CM, Davey KR (2002) Iron-core coils for transcranial magnetic stimulation. J Clin Neurophysiol 19:376-381. CrossRef Medline

Feldheim DA, Kim YI, Bergemann AD, Frisén J, Barbacid M, Flanagan JG (2000) Genetic analysis of ephrin-A2 and ephrin-A5 shows their requirement in multiple aspects of retinocollicular mapping. Neuron 25:563574. CrossRef Medline

Fernandez EA, Ohlemiller KK, Gagnon PM, Clark WW (2010) Protection against noise-induced hearing loss in young CBA/J mice by low-dose kanamycin. JARO 11:235-244. CrossRef Medline

Fitzgerald M, Buckley A, Lukehurst SS, Dunlop SA, Beazley LD, Rodger J (2008) Neurite responses to ephrin-A5 modulated by BDNF: evidence for TrkB-EphA interactions. Biochem Biophys Res Commun 374:625630. CrossRef Medline

Franklin K, Paxinos G (2008) The mouse brain in stereotaxic coordinates, Ed 3. New York: Academic.

Gersner R, Kravetz E, Feil J, Pell G, Zangen A (2011) Long-term effects of repetitive transcranial magnetic stimulation on markers for neuroplasticity: Differential outcomes in anesthetized and awake animals. J Neurosci 31:7521-7526. CrossRef Medline

Gianfranceschi L, Siciliano R, Walls J, Morales B, Kirkwood A, Huang ZJ, Tonegawa S, Maffei L (2003) Visual cortex is rescued from the effects of dark rearing by overexpression of BDNF. Proc Natl Acad Sci U S A 100: 12486-12491. CrossRef Medline

Grehl S, Viola H, Sherrard R, Dunlop S, Hool L, Rodger J (2011) The influence of repetitive pulsed magnetic stimulation on neuronal cultures. Presented at IBRO, Florence, Italy.

Grillo FW, Song S, Teles-Grilo Ruivo LM, Huang L, Gao G, Knott GW, Maco B, Ferretti V, Thompson D, Little GE, De Paola V (2013) Increased axonal bouton dynamics in the aging mouse cortex. Proc Natl Acad Sci U S A 110:E1514-E1523. CrossRef Medline

Hamada M, Terao Y, Hanajima R, Shirota Y, Nakatani-Enomoto S, Furubayashi T, Matsumoto H, Ugawa Y (2008) Bidirectional long-term motor cortical plasticity and metaplasticity induced by quadripulse transcranial magnetic stimulation. J Physiol 586:3927-3947. CrossRef Medline

Haustead DJ, Lukehurst SS, Clutton GT, Bartlett CA, Dunlop SA, Arrese CA, Sherrard RM, Rodger J (2008) Functional topography and integration of the contralateral and ipsilateral retinocollicular projections in ephrin$\mathrm{A}^{-1-}$ mice. J Neurosci 28:7376-7386. CrossRef Medline

Hicks RR, Numan S, Dhillon HS, Prasad MR, Seroogy KB (1997) Alterations in BDNF and NT-3 mRNAs in rat hippocampus after experimental brain trauma. Mol Brain Res 48:401-406. CrossRef Medline

Huang ZJ, Kirkwood A, Pizzorusso T, Porciatti V, Morales B, Bear MF, Maffei L, Tonegawa S (1999) BDNF regulates the maturation of inhibition and the critical period of plasticity in mouse visual cortex. Cell 98:739-755. CrossRef Medline

Inoue K, Terashima T, Inoue Y (1992) Postnatal development of the corticotectal projection from the visual cortex of the mouse. Okajimas Folia Anat Jpn 68:319-331. CrossRef Medline

Iyer MB, Schleper N, Wassermann EM (2003) Priming stimulation enhances the depressant effect of low-frequency repetitive transcranial magnetic stimulation. J Neurosci 23:10867-10872. Medline

Kähkönen S, Komssi S, Wilenius J, Ilmoniemi RJ (2005) Prefrontal transcranial magnetic stimulation produces intensity-dependent EEG responses in humans. Neuroimage 24:955-960. CrossRef Medline

Kuczewski N, Langlois A, Fiorentino H, Bonnet S, Marissal T, Diabira D, Ferrand N, Porcher C, Gaiarsa JL (2008) Spontaneous glutamatergic activity induces a BDNF-dependent potentiation of GABAergic synapses in the newborn rat hippocampus. J Physiol 586:5119-5128. CrossRef Medline

Lang N, Harms J, Weyh T, Lemon RN, Paulus W, Rothwell JC, Siebner HR (2006) Stimulus intensity and coil characteristics influence the efficacy of rTMS to suppress cortical excitability. Clin Neurophysiol 117:2292-2301. CrossRef Medline

Lee L, Siebner HR, Rowe JB, Rizzo V, Rothwell JC, Frackowiak RS, Friston KJ (2003) Acute remapping within the motor system induced by lowfrequency repetitive transcranial magnetic stimulation. J Neurosci 23: 5308-5318. Medline

Lefaucheur JP (2009) Methods of therapeutic cortical stimulation. Neurophysiologie Clinique 39:1-14. CrossRef Medline

Luikart BW, Parada LF (2006) Receptor tyrosine kinase B-mediated excitatory synaptogenesis. Prog Brain Res 157:15-24. CrossRef Medline

Maeda F, Keenan JP, Tormos JM, Topka H, Pascual-Leone A (2000) Modulation of corticospinal excitability by repetitive transcranial magnetic stimulation. Clin Neurophysiol 111:800-805. CrossRef Medline

Majdan M, Miller FD (1999) Neuronal life and death decisions: functional antagonism between the Trk and p75 neurotrophin receptors. Int J Dev Neurosci 17:153-161. CrossRef Medline

Mandolesi G, Menna E, Harauzov A, von Bartheld CS, Caleo M, Maffei L (2005) A role for retinal brain-derived neurotrophic factor in ocular dominance plasticity. Curr Biol 15:2119-2124. CrossRef Medline

Marler KJ, Becker-Barroso E, Martínez A, Llovera M, Wentzel C, Poopalasundaram S, Hindges R, Soriano E, Comella J, Drescher U (2008) A TrkB/EphrinA interaction controls retinal axon branching and synaptogenesis. J Neurosci 28:12700-12712. CrossRef Medline

Marler KJ, Poopalasundaram S, Broom ER, Wentzel C, Drescher U (2010) Proneurotrophins secreted from retinal ganglion cell axons are necessary for ephrinA-p75NTR-mediated axon guidance. Neural Dev 5:30. CrossRef Medline Martin SJ, Grimwood PD, Morris RG (2000) Synaptic plasticity and mem- 
ory: an evaluation of the hypothesis. Annu Rev Neurosci 23:649-711. CrossRef Medline

Martiny K, Lunde M, Bech P (2010) Transcranial low voltage pulsed electromagnetic fields in patients with treatment-resistant depression. Biol Psychiatry 68:163-169. CrossRef Medline

Mattsson MO, Simkó M (2012) Is there a relation between extremely low frequency magnetic field exposure, inflammation and neurodegenerative diseases? A review of in vivo and in vitro experimental evidence. Toxicology 301:1-12. CrossRef Medline

Maya Vetencourt JF, Sale A, Viegi A, Baroncelli L, De Pasquale R, O'Leary OF, Castrén E, Maffei L (2008) The antidepressant fluoxetine restores plasticity in the adult visual cortex. Science 320:385-388. CrossRef Medline

McLaughlin T, O’Leary DD (2005) Molecular gradients and development of retinotopic maps. Annu Rev Neurosci 28:327-355. CrossRef Medline

McLaughlin T, Torborg CL, Feller MB, O'Leary DD (2003) Retinotopic map refinement requires spontaneous retinal waves during a brief critical period of development. Neuron 40:1147-1160. CrossRef Medline

McQuillen PS, DeFreitas MF, Zada G, Shatz CJ (2002) A novel role for p75NTR in subplate growth cone complexity and visual thalamocortical innervation. J Neurosci 22:3580-3593. Medline

Morgado-Valle C, Verdugo-Díaz L, García DE, Morales-Orozco C, DruckerColín R (1998) The role of voltage-gated $\mathrm{Ca}^{2+}$ channels in neurite growth of cultured chromaffin cells induced by extremely low frequency (ELF) magnetic field stimulation. Cell Tissue Res 291:217-230. CrossRef Medline

Naska S, Lin DC, Miller FD, Kaplan DR (2010) p75NTR is an obligate signaling receptor required for cues that cause sympathetic neuron growth cone collapse. Mol Cell Neurosci 45:108-120. CrossRef Medline

Park JB, Yiu G, Kaneko S, Wang J, Chang J, He ZL, Garcia KC, He Z (2005) A TNF receptor family member, TROY, is a coreceptor with Nogo receptor in mediating the inhibitory activity of myelin inhibitors. Neuron 45: 345-351. CrossRef Medline

Pascual-Leone A (2006) Disrupting the brain to guide plasticity and improve behavior. Prog Brain Res 157:315-329. CrossRef Medline

Pell GS, Roth Y, Zangen A (2011) Modulation of cortical excitability induced by repetitive transcranial magnetic stimulation: influence of timing and geometrical parameters and underlying mechanisms. Prog Neurobiol 93:59-98. CrossRef Medline

Pessina GP, Aldinucci C, Palmi M, Sgaragli G, Benocci A, Meini A, Pessina F (2001) Pulsed electromagnetic fields affect the intracellular calcium concentrations in human astrocytoma cells. Bioelectromagnetics 22:503-510. CrossRef Medline

Poo M (1981) In situ electrophoresis of membrane components. Annu Rev Biophys Bioeng 10:245-276. CrossRef Medline

Prato FS, Thomas AW, Cook CM (2005) Extremely low frequency magnetic fields (ELFMF) and pain therapy. In: Advances in electromagnetic fields in living systems (Lin J, ed), pp 155-187. New York: Springer.

Quigley HA, McKinnon SJ, Zack DJ, Pease ME, Kerrigan-Baumrind LA, Kerrigan DF, Mitchell RS (2000) Retrograde axonal transport of BDNF in retinal ganglion cells is blocked by acute IOP elevation in rats. Invest Ophthalmol Vis Sci 41:3460-3466. Medline

Reithler J, Peters JC, Sack AT (2011) Multimodal transcranial magnetic stimulation: Using concurrent neuroimaging to reveal the neural network dynamics of noninvasive brain stimulation. Prog Neurobiol 94:149-165. CrossRef Medline

Rickman DW, Brecha NC (1995) Expression of the proto-oncogene, trk, receptors in the developing rat retina. Vis Neurosci 12:215-222. CrossRef Medline

Robertson JA, Théberge J, Weller J, Drost DJ, Prato FS, Thomas AW (2010) Low-frequency pulsed electromagnetic field exposure can alter neuroprocessing in humans. J R Soc Interface 7:467-473. CrossRef Medline

Rodger J, Mo C, Wilks T, Dunlop SA, Sherrard RM (2012) Transcranial pulsed magnetic field stimulation facilitates reorganization of abnormal neural circuits and corrects behavioral deficits without disrupting normal connectivity. FASEB J 26:1593-1606. CrossRef Medline

Rounis E, Stephan KE, Lee L, Siebner HR, Pesenti A, Friston KJ, Rothwell JC, Frackowiak RS (2006) Acute changes in frontoparietal activity after repetitive transcranial magnetic stimulation over the dorsolateral prefrontal cortex in a cued reaction time task. J Neurosci 26:9629-9638. CrossRef Medline

Sale A, Maya Vetencourt JF, Medini P, Cenni MC, Baroncelli L, De Pasquale R, Maffei L (2007) Environmental enrichment in adulthood promotes amblyopia recovery through a reduction of intracortical inhibition. Nat Neurosci 10:679-681. CrossRef Medline
Sale A, Berardi N, Maffei L (2009) Enrich the environment to empower the brain. Trends Neurosci 32:233-239. CrossRef Medline

Salvador R, Miranda PC (2009) Transcranial magnetic stimulation of small animals: A modeling study of the influence of coil geometry, size and orientation. Presented at the 31st Annual International Conference of the IEEE. CrossRef

Schecterson LC, Bothwell M (2010) Neurotrophin receptors: Old friends with new partners. Dev Neurobiol 70:332-338. CrossRef Medline

Sefton AJ, Dreher B, Harvey AR (2004) Visual system. In: The rat nervous system, Ed 3 (Paxinos G, ed), pp 1083-1165. San Diego: Elsevier.

Sherrard RM, Dixon KJ, Bakouche J, Rodger J, Lemaigre-Dubreuil Y, Mariani J (2009) Differential expression of TrkB isoforms switches climbing fiber-Purkinje cell synaptogenesis to selective synapse elimination. Dev Neurobiol 69:647-662. CrossRef Medline

Shu Y, Hasenstaub A, Duque A, Yu Y, McCormick DA (2006) Modulation of intracortical synaptic potentials by presynaptic somatic membrane potential. Nature 441:761-765. CrossRef Medline

Siebner HR, Lang N, Rizzo V, Nitsche MA, Paulus W, Lemon RN, Rothwell JC (2004) Preconditioning of low-frequency repetitive transcranial magnetic stimulation with transcranial direct current stimulation: evidence for homeostatic plasticity in the human motor cortex. J Neurosci 24:3379-3385. CrossRef Medline

Sieroń A, Labus Ł, Nowak P, Cieślar G, Brus H, Durczok A, Zagził T, Kostrzewa RM, Brus R (2004) Alternating extremely low frequency magnetic field increases turnover of dopamine and serotonin in rat frontal cortex. Bioelectromagnetics 25:426-430. CrossRef Medline

Silver MA, Stryker MP (2001) TrkB-like immunoreactivity is present on geniculocortical afferents in layer IV of kitten primary visual cortex. J Comp Neurol 436:391-398. CrossRef Medline

Singh KK, Miller FD (2005) Activity regulates positive and negative neurotrophin-derived signals to determine axon competition. Neuron 45:837-845. CrossRef Medline

Singh KK, Park KJ, Hong EJ, Kramer BM, Greenberg ME, Kaplan DR, Miller FD (2008) Developmental axon pruning mediated by BDNF-p75NTRdependent axon degeneration. Nat Neurosci 11:649-658. CrossRef Medline

Spalding KL, Tan MM, Hendry IA, Harvey AR (2002) Anterograde transport and trophic actions of BDNF and NT-4/5 in the developing rat visual system. Mol Cell Neurosci 19:485-500. CrossRef Medline

Sykes M, Makowiecki K, Rodger J (2013) Long term delivery of pulsed magnetic fields does not alter visual discrimination learning or dendritic spine density in the mouse CA1 pyramidal or dentate gyrus neurons. F1000Res 2:180. CrossRef Medline

Szapacs ME, Mathews TA, Tessarollo L, Ernest Lyons W, Mamounas LA, Andrews AM (2004) Exploring the relationship between serotonin and brain-derived neurotrophic factor: analysis of BDNF protein and extraneuronal 5-HT in mice with reduced serotonin transporter or BDNF expression. J Neurosci Methods 140:81-92. CrossRef Medline

Thickbroom GW (2007) Transcranial magnetic stimulation and synaptic plasticity: experimental framework and human models. Exp Brain Res 180:583-593. CrossRef Medline

Thickbroom GW, Mastaglia FL (2009) Plasticity in neurological disorders and challenges for noninvasive brain stimulation (NBS). J Neuroeng Rehabil 6:4. CrossRef Medline

Triplett JW, Owens MT, Yamada J, Lemke G, Cang J, Stryker MP, Feldheim DA (2009) Retinal input instructs alignment of visual topographic maps. Cell 139:175-185. CrossRef Medline

Ugolini G, Cremisi F, Maffei L (1995) TrkA, TrkB and p75 mRNA expression is developmentally regulated in the rat retina. Brain Res 704:121-124. CrossRef Medline

Valero-Cabré A, Payne BR, Rushmore J, Lomber SG, Pascual-Leone A (2005) Impact of repetitive transcranial magnetic stimulation of the parietal cortex on metabolic brain activity: a $14 \mathrm{C}-2 \mathrm{DG}$ tracing study in the cat. Exp Brain Res 163:1-12. CrossRef Medline

Valero-Cabré A, Payne BR, Pascual-Leone A (2007) Opposite impact on 14C-2-deoxyglucose brain metabolism following patterns of high and low frequency repetitive transcranial magnetic stimulation in the posterior parietal cortex. Exp Brain Res 176:603-615. CrossRef Medline

Valero-Cabré A, Pascual-Leone A, Rushmore RJ (2008) Cumulative sessions of repetitive transcranial magnetic stimulation (rTMS) build up facilitation to subsequent TMS-mediated behavioural disruptions. Eur J Neurosci 27:765-774. CrossRef Medline 
Volz LJ, Benali A, Mix A, Neubacher U, Funke K (2013) Dose-dependence of changes in cortical protein expression induced with repeated transcranial magnetic theta-burst stimulation in the rat. Brain Stimul 6:598-606. CrossRef Medline

Wagner T, Rushmore J, Eden U, Valero-Cabré A (2009) Biophysical foundations underlying TMS: Setting the stage for an effective use of neurostimulation in the cognitive neurosciences. Cortex 45:10251034. CrossRef Medline

Wassermann EM, Zimmermann T (2012) Transcranial magnetic brain stimulation: therapeutic promises and scientific gaps. Pharmacol Ther 133:98-107. CrossRef Medline

Weissman JD, Epstein CM, Davey KR (1992) Magnetic brain stimulation and brain size: relevance to animal studies. Electroencephalogr Clin Neurophysiol 85:215-219. CrossRef Medline

West MJ (1993) New stereological methods for counting neurons. Neurobiol Aging 14:275-285. CrossRef Medline

Wilks TA, Rodger J, Harvey AR (2010) A role for ephrin-As in maintaining topographic organization in register across interconnected central visual pathways. Eur J Neurosci 31:613-622. CrossRef Medline

Yates N, Robertson D, Martin-Iverson M, Rodger J (2014) Auditory brainstem responses of ephrin-A2, ephrin-A5 $\left(^{-1-}\right)$ and ephrin-A2A $5\left(^{-1-}\right)$ mice. Audiol Neurootol 19:115-126. CrossRef Medline

Yu Y, Maureira C, Liu X, McCormick D (2010) P/Q and N channels control baseline and spike-triggered calcium levels in neocortical axons and synaptic boutons. J Neurosci 30:11858-11869. CrossRef Medline

Zafra F, Hengerer B, Leibrock J, Thoenen H, Lindholm D (1990) Activitydependent regulation of BDNF and NGF mRNAs in the rat hippocampus is mediated by non-NMDA glutamate receptors. EMBO J 9:3545-3550. Medline

Zangen A, Roth Y, Voller B, Hallett M (2005) Transcranial magnetic stimulation of deep brain regions: evidence for efficacy of the H-Coil. Clin Neurophysiol 116:775-779. CrossRef Medline

Ziemann U, Paulus W, Nitsche MA, Pascual-Leone A, Byblow WD, Berardelli A, Siebner HR, Classen J, Cohen LG, Rothwell JC (2008) Consensus: motor cortex plasticity protocols. Brain Stimul 1:164-182. CrossRef Medline 